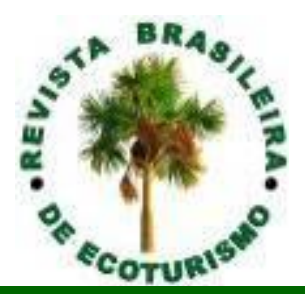

\title{
Marine ecotourism in Brazil: from origins to implementation feasibility
}

\author{
Ecoturismo marinho no Brasil: das origens à viabilidade \\ de implementação
}

Alexandre de Gusmão Pedrini

\begin{abstract}
This literature review aims at analyzing and reflecting upon the genesis of marine ecotourism in Brazil from an environmental education perspective. It covers the study of two representative cases of marine ecotourism along the Brazilian coast, which develop direct benthic-community watching - one on rocky shores (EcoTurisMar Project) and another on coral reefs (ProMar Project). ProMar, implemented in Environmental Protection Area of Tinharé and Boipeba Islands, sells products by US\$16 each and generates about US\$ 430 every ten days. Main constraints to sustainable marine ecotourism identified by the study were: a) lack of governmental funding for the development of sustainable marine ecotouristic products; b) absence of laws making it mandatory for tour operators to offer sustainable marine ecotouristic products inside and around protected areas; c) higher costs of marine ecotouristic products in comparison with mainstream touristic products; d) local traders' lack of interest in undertaking sustainable marine ecotouristic products; e) funding and general choice for environmentally damaging mainstream touristic products; f) lack of low-interest public funding for community-based ecotouristic enterprises; g) governmental divestment from public universities - and thus from faculty's projects; $h$ ) dismantling of socioenvironmental governmental agencies liable for control and surveillance, especially in relation to marine fauna-watching ecotourism. Results suggest the urgency of an in loco inventory of marine ecotourism activities in Brazil. By taking into consideration the input from several stakeholders engaged in touristic trade, sustainable marine ecotourism can be implemented in a way that comprehends all kinds of sustainability.
\end{abstract}

KEYWORDS: Trails; Ecotourism; Environmental Education; South America; Atlantic Coast. 


\section{RESUMO}

Esse artigo de revisão sintetiza e reflete criticamente sobre a gênese do ecoturismo marinho no Brasil, sob a perspectiva da educação ambiental. $O$ trabalho se concentra em dois estudos de casos emblemáticos de observação da comunidade bentônica marinha costeira. Um caso é o Projeto EcoTurisMar desenvolvido para observação da comunidade bentônica de costões rochosos marinhos no sudeste e o outro caso é o Projeto ProMar realizado para reconhecimento da vida marinha dos recifes de coral no nordeste brasileiro. $O$ Projeto que mais avançou foi o ProMar implementado na Área de Proteção Ambiental das Ilhas de Tinharé e Boipeba no Estado da Bahia. Ele vende cada produto por US $\$ 16$ e acumula US $\$ 430$ a cada 10 dias. As principais dificuldades identificadas para a sustentabilidade do ecoturismo marinho local são: a) falta de financiamento inicial do governo local para o desenvolvimento de produtos ecoturísticos; b) ausência de legislação que obrigue às operadoras de turismo locais a oferecer produtos de ecoturismo marinho sustentáveis nos limites das áreas protegidas; c) custo mais alto dos produtos de ecoturismo marinho de base local quando comparados com os do turismo marinho massificados e insustentáveis; d) desinteresse dos empresários de turismo local em desenvolver e vender o ecoturismo marinho sustentável local; e) escolha do público pelo turismo marinho que danifica a biota local; f) desinteresse da população local em criar empresas de ecoturismo; g) desinvestimento governamental nas universidades públicas e consequentemente falta de dinheiro para desenvolvimento de projetos universitários como os de ecoturismo marinho; $h$ ) desconstrução das agências governamentais de fiscalização sociambiental especialmente em relação a observação ecoturística da fauna marinha. Os resultados mostram a necessidade urgente de um inventário das atividades comerciais de ecoturismo marinho no Brasil. É necessário conhecer as contribuições e interesses dos vários atores envolvidos no setor comercial. Para o ecoturismo marinho ser amplamente implementado comercialmente no país com sustentabilidade socioambiental é necessário superar e resolver os obstáculos já identificados.

PALAVRAS-CHAVE: Trilhas; Ecoturismo; Educação Ambiental; América do Sul; Oceano Atlântico.

\section{Introduction}

Ecotourism moves ca. US\$10-17 billions around the world, according to Fennell (1998). As an economic activity, its human impact is wide, enabling thousands of direct and indirect jobs, tax collection and wealth generation (WTO, 2004). There is no specific data about global wealth generation by ME (Marine Ecotourism). This is likely due to the range of practices it involves many of which are still informal and do not produce reliable statistics.

Some countries consider certain activities to be ME, whereas others call them adventure tourism. Scuba-diving, for instance, is regarded as adventure tourism in Brazil (LIMA, 2000; BEARD et al., 2003). Internationally, however, it is seen as ME (GARROD et al., 2003; PETREAS, 2003; TOWNSEND, 2003). The following activities, nevertheless, are internationally comprehended by the ME category: a) snorkel-aided lectures along interpretive or non-interpretive trails, with landscape, subsea or estuarine-ecosystem watching; b) 
charismatic-organism watching, which includes whales, dolphins, porpoises, turtles, seals, sea lions, fish such as sharks and groupers and seabirds such as albatrosses and petrels. In several places around the globe, however, snorkeling along marine trails is not treated as ME (BAUDE et al., 2012). In order to join the category, they should adopt its principles, such as localcommunity engagement and participant-number restrictions of up to 25 people for each product.

Forestell (1993) was the first North-American environmental educator to propose MEE (Marine Environmental Education) via an ME product aimed at whale watching in Hawaii, concluding as to the existence of limitations concerning the experience's time limit and instructors' poor training. Only in the end of the $20^{\text {th }}$ century has ME suffered improvements within the field of coastal tourism, with several successful cases around the planet. Table 1 presents some examples of activities classified as ME according to the Brazilian concept, showing the prevalence of recent projects, implemented in the $21^{\text {st }}$ century, by primarily tropical and subtropical countries.

A crucial aspect to ME enterprises is funding, especially in developing countries. Ranweli Holiday Village project in Sri Lanka, for instance, which includes mangrove visitation, was selected to represent its country in a bestpractice collection published by the United Nations World Tourism Organization. Ranweli is a resort encompassing 84 housing units, the construction of which cost about US\$ 2 billion. Out of its 160 employees, ca. $43 \%$ are locals (WTO, 2004).

Table 1: ME projects and enterprises in international literature.

Tabela 1: Projetos e empresas de Ecoturismo Marinho na literatura internacional

\begin{tabular}{|l|l|l|l|l|l|}
\hline No & Country & \multicolumn{1}{|c|}{ Author(s) } & No & \multicolumn{1}{c|}{ Country } & \multicolumn{1}{c|}{ Author(s) } \\
\hline 1 & Brazil & $\begin{array}{l}\text { Pedrini et al. (2016b, } \\
\text { 2018);Rhormens et } \\
\text { al. (2017) }\end{array}$ & 6 & Timor-Leste & Edyvane et al. (2009) \\
\hline 2 & Egypt & Hannak et al. (2011) & 7 & Malaysia & Musa (2003) \\
\hline 3 & Philippines & WTO (2004) & 8 & New Zealand & Orams (2003) \\
\hline 4 & India & Chakravarty (2003) & 9 & Portugal & $\begin{array}{l}\text { Rangel et al. (2009), } \\
\text { Oliveira et al. (2011) }\end{array}$ \\
\hline 5 & Indonesia & $\begin{array}{l}\text { Rahakbauw et al. } \\
(2017)\end{array}$ & 10 & Sri Lanka & WTO (2004) \\
\hline
\end{tabular}

Brazil's coastal zone relies on several protection policies approved in accordance with the government and the population's recognition of their importance. Among them, two stand out: the National Policy for the Environment (Política Nacional do Meio Ambiente - Pnma) (BRASIL, 1981) and the National Plan for Coastal Management (Plano Nacional de Gerenciamento Costeiro) (BRASIL, 1988). However, they have fallen short of preventing Brazilian shore's degradation, as well as several middle to largeimpact incidents and accidents.

In accordance with both policies (cf. PEDRINI, 2018), one of the most significant studies of the Brazilian coast is the Wide-Scale Diagnosis of the Brazilian Coastal and Marine Zone (MMA, 2008). This instrument for territorial 
management gathers scientific information at national level, thus strengthening cooperation between the organizations which constitute the National System for the Environment (Sistema Nacional de Meio Ambiente - Sisnama). Its cartography comprises the entire coast, presenting several data on oceanography and environmental risk, for instance. Nicolodi and Zamboni (2008) present several instruments and actions for coastal management, out of which they highlight nine: a) Seashore Project (Projeto Orla); b) Agenda 21; c) City Master Plans; d) Environmental Municipal Councils; e) EconomicEcological Coastal Zoning; f) Oil and Gas Temporary Exclusion Zones; g) Protected Areas; h) Oil-Sensitivity Shore Mapping; i) Population Estimates for Brazilian cities by the Brazilian Institute of Geography and Statistics (Instituto Brasileiro de Geografia e Estatística). The $4^{\text {th }}$ Federal Action Plan for the Coastal Zone (BRASIL, 2017) is the specific policy currently in force, the construction of which included scientists, businesspeople, city, state and country-level officers etc. The final document, aligned with the United Nations' Sustainable Development Goals, includes funding lines, suggesting a setting which favors the development of new coastal management ideas and products.

According to Marroni and Asmus (2005), managing coastal zone actions is intimately connected to sustainability, drawing from sustainable development. In line with the ideas of Paulo Freire $(1996,1999)$, the authors contend that only through political education - as in TEEE - (Transformative and Emancipatory Environmental Education) is it possible to change citizens' awareness and enable them to envisage a new viable planet for all human civilization. Several authors support such statement, such as Sorrentino et al. (2005), Loureiro (2009), Quintas (2009), Saito et al. (2014) and Pedrini et al. (2016a, 2016b).

In Brazil, however, ME is not yet widely developed as a commercial activity. Besides, no empirical study so far has identified and listed the country's ME activities. This article briefly presents four representative projects which involve commercial ME actions or intentions in Brazil. As a collaborating scientist in the development of two ME products (PEDRINI et al. 2011, 2013a, 2013b, 2015, 2016b; PEDRINI 2017, 2018; RHORMENS et al. 2017), I shall signal to some of their implementation challenges. The awareness of public universities' role in realizing science's social contract (PEDRINI; DE-PAULA, 2011) has driven me into providing society with knowledge and products in order to solve their income and work problems (EcoTurisMar and ProMar projects). Community-based $\mathrm{ME}$ in caiçara ${ }^{1}$ communities along the Brazilian coast carries the potential to become an alternative coherent with the foundations of socioenvironmental sustainability.

\section{Ecotourism in Brazil}

According to the Brazilian Institute for Tourism (EMBRATUR, 1999), ecotourism was expected to move more than US\$11 billion in Brazil in 2005. No piece of information available, however, confirms or denies such estimates. Governmental optimism towards the sector, however, indicates the importance of understanding its trajectory in the country. 
As a concept, ecotourism is polysemous. According to Furlan (2003), some years ago it was still confused with EE initiatives strongly influenced by social movements and biology/science teachers. In Brazil, commercial enterprises offer the promise of ecotouristic products. In general they opportunistically take advantage of the marketing appeal and social demand for more playful and healthy environments, which they relate to products whose name is complemented by the radical "eco" (RODRIGUES, 2003). The radical is drawn for the scientific word "ecology", a branch of biology which studies the relations between organisms and their environment. However, Coriolano (2003), Gomes (2003), Ruschmann (2005), Pedrini (2007), Pedrini and Meriano (2007) and several researchers have demonstrated companies' discursive contradictions as to their ecotouristic products, which back then were hardly ecological.

In order to understand Brazilian ecotourism' modus operandi, Professor Adyr Balastreri Rodrigues (2003) has proposed the classification I shall adapt in this paper, which categorizes main sectors according to the manifold stakeholders involved:

a) Business sector: monitors market variations and changes in consumers' desire and taste, so as to plan and provide products; must understand what society wants concerning distinct ecotouristic products including ME with ecological information in small groups.

b) Environmentalist sector, mostly represented by NGOs: encompasses a wide array of entities with different and often conflicting interests, which range from providing socioenvironmental sustainability in ecotouristic enterprises with no international interference to promoting community economic development with international funding.

c) State sector: vital partner in all three - city, state and country spheres, its responsibilities should not be taken over by NGOs (nongovernmental organizations), often interested in replacing it (due to its total absence or omission), such as in listening to organized society's claims, mediating and resolving conflict situations, removing legal obstacles to local development, promoting new judicial instruments that enable self-determined development, offering broad support to strengthen community and providing managerial staff for the task.

d) Ecotourists: the need for establishing a standard profile faces the existence of four basic types: 1) ecotourist-researchers from universities and NGOs, who act at times as authentic ecotourists, at times as researchers; 2) researcher ecotourists, interested in research groups in high-geobiodiversity regions, who may engage with scientific experiments conducted within the products; 3) naturalist ecotourists who enjoy traveling to areas of very high biodiversity to watch whales or specific ecosystems, such as coral reefs; 4) casual ecotourists with no specific interest, keen on visiting areas of ecotouristic relevance.

e) Educational institutions (university or high-school level) committed with realizing science's social contract (cf. PEDRINI, 2011) either with localcommunity initiatives or with the scholar agenda. 
f) Host communities acting as ecotourism's main partners, which do not always appear integrated or cohesive towards tour operators responsible for ecotouristic products, their participation may be split into four kinds: 1) imposed, when product operators or producers have not listened to their desires, needs and opinions; 2) consulted, when operator-community dialogue is fostered so as to debate and evaluate potential problems - especially financial; 3) externally aided endogenous, when communities propel collaboration, managing financial resources and making autonomous decisions; 4) endogenous, when community leadership is spontaneous and relies on no external support.

Ecotourism's conceptual imprecision favors a myriad of understandings and confusing equivalences with alternative, green, in-nature or environmental tourism (PEDRINI, 2007; ZAÚ, 2014). According to Pires (2005), ecotourism or ecological tourism is a segment of in-nature tourism - which informs a purely biologizing definition. Its dangers and anticultural bias may deprive products of the visitation of human communities which have long inhabited the ecosystem, such as ancestral traditional populations. Its consequences are particularly pernicious for the Brazilian Atlantic Forest, where existing caiçara and indigenous communities have a rich cultural heritage to show ecotourists (DIEGUES, 1999). The lack of conceptual uniformity for ecotourism as a commercial product has another detrimental aspect: the exclusion of host communities from sharing the product's benefits. Sales should be partially made in site, to allow immediate and in-cash benefit distribution.

The Brazilian government provides no surveillance to enforce ecotourists' rights at the moment of purchasing a touristic or ecotouristic product in the national market. Should tour operators fail partially or entirely in meeting products' announced features, citizens will need to hire legal assistance. Or, according to the National Consumer Act (BRASIL, 1990), they should seek public defenders and join a long queue to claim their rights against operators.

Many companies thus bet on consumer conformism, leading to a potential degradation of Brazilian ecotourism. Traders with no concern for the socioenvironmental cause or commercial ethics offer products in absolute disconnection with the environment, aimed exclusively at unethical commercial and financial benefit. Several authors have commented on the business sector's incompliance by offering ecotouristic products incoherent with ecotourism's foundations (RODRIGUES, 2003). Antunes and Rabinovici's (2010) study on ethic and sustainability in Brazilian tourism identified the inexistence of an international ecotourism-specific code of ethics. The only comparable text is the Code of Ethics for Tourism, published by WTO (1999), reinforcing the urgency of creating a specific code to encompass specificities such as those pertaining ME.

Until 2016, the Brazilian government demonstrated interest in strengthening ecotourism, even if in a decentralized fashion - which could weaken public budget allocation. At federal administration level, two departments have managed ecotourism policies. The Department for the Environment witnessed their genesis and early definitions in an implicit 
integrating policy called Guidelines for a National Ecotourism Policy (Diretrizes para uma Política Nacional de Ecoturismo), published in 1995. Its concept persisted in the National Program for Ecotourism in the Amazon (Programa Nacional de Ecoturismo para a Amazônia - Proecotur) (BRASIL, 1995), which gained national policy status after published, in 1998. The policy was later strengthened, according to Paula and Rabinovici (2010), by the program Ecotourism Spots (Pólos do Ecoturismo), published in 2001 - a policy whose efficacy, however, remains unevaluated.

The Department for Tourism (BRASIL, 2010) has published an interesting document written by a renowned working group, called Ecotourism: Basic Guidelines (Ecoturismo: orientações básicas). It includes representatives from both civil society and the Brazilian Society for Ecotourism, which I have directed and publishes the Brazilian Ecotourism Journal (Revista Brasileira de Ecoturismo). Among the publication's recommendations, a classification suggests a way to categorize activities in the country: a) geobiodiversity (fauna, flora and geology) watching; b) cave visitation (speleotourism); c) astronomical observation (sky watching at night); d) snorkeling inside rivers, sea, lakes and caves; e) pre-defined-course walks; f) self- or professionally guided/conducted walks along interpretive trails; g) photographic safaris. As mentioned before, scuba-diving is not recognized as ME in Brazil, but rather as diving tourism.

Proecotur (BRASIL, 2002a), a policy currently in force, has the following specific goals: a) protecting and developing touristic attractions; b) implementing basic service infrastructure; c) creating favorable conditions for investment; d) evaluating national and international markets; e) proposing regulations for ecotourism; f) building capacity among human resources; g) fostering the use of appropriate technologies; h) valuing local cultures; i) contributing with funding for biodiversity conservation. The previously established ecotourist profile, which informs operator's supply of ecotouristic products, deserves attention: a) they live in big cities and want to know preserved natural environments; b) they seek for information on places to visit; c) they enjoy learning about the environment and local communities' daily lives; d) they prefer to feel as a part of the natural environment and the visited community; e) they worry about environmental quality, as well as about host communities' well-being. This policy's efficacy in line with its goals has not been evaluated to my knowledge.

The Brazilian government has displayed contradictory attitudes towards promoting ecotourism in the past ten years. MMA provides considerably more incentives to ecotourism than the Department for Tourism. Its important study (MMA, 2010) about coastal and marine ecosystem conservation in the country, for instance, demonstrates the existence of considerable room for economically sustainable activities - such as ecotourism - at the Brazilian coast. Kinker (2005) has produced comprehensive work on the inclusion of ecotourism in Brazilian national parks. Besides parks, other kinds of protected area may implement ecotourism inside and outside their limits. However, formal ecotourism policies currently behoove the Department for Tourism, which passed the second National Plan for Tourism (BRASIL, 2013), which nevertheless guaranteed nothing for tourism neither ecotourism. Ecotourism 
currently relies on no evident or substantial funding from both federal departments, whose websites in March 2018 have shown no significant information concerning existing investments in the segment.

Historically, however, (marine) ecotourism in Brazil did not stem from either environmental or touristic, but rather from (marine) EE activities - whose initiatives thus become especially relevant.

\section{Marine environmental perception and education in Brazil}

The Brazilian coastal zone covers an area of approx. $514,000 \mathrm{~km}^{2}$, 324,000 of which belong to the territory of 395 cities in 17 coastal states, including internal waters and the remaining territorial sea. Its 8,698-km-long shoreline encompasses diverse ecosystems, such as coral reefs, sandstones, mangroves $\left(25,000 \mathrm{~km}^{2}\right)$, rocky coasts, sandy beaches, rhodolite and marine angiosperm beds, atolls etc. (MMA, 2008).

Brazil has several policies aimed at protecting marine and estuarine ecosystems (PEDRINI, 2018), among which one is especially worth mentioning. The National System for Natural Protected Areas (Sistema Nacional de Unidades de Conservação da Natureza - SNUC) (BRASIL, 2002b) outlines a number of ecosystem conservation categories, such as biological reserves, national and state parks, natural monuments and marine environmental protection areas. Marine ecosystems, however, are not always safe. The population has witnessed incidents and accidents on the Brazilian coast, caused by many companies, while official authorities are often shorthanded in view of the geographical vastness they are supposed to surveil.

Regardless of occasional large-impact accidents and incidents caused by companies, negative impacts are daily caused by beachgoers, tourists and divers. Noteworthy studies by Bertuol (2005), Pedrini et al. (2007, 2008b), Silva and Ghilardi-Lopes (2012), Tunala et al. (2013), Santos et al. (2015) and Calado (2018) delve upon the impacts of trampling on benthic fauna and flora, as well as upon its intentional or unintentional removal. Berchez et al. (2005, 2007) and Pedrini et al. $(2009,2010)$ have shown that simple technical briefing in an EE setting before diving drastically reduce negative impacts on marine biological communities.

Thus have universities, NGOs and the government itself invested in environmental perception and education. For that purpose, these stakeholders have lobbied for policies which were gradually approved, such as the National Environmental Education Policy (Política Nacional de Educação Ambiental PNEA) (BRASIL, 1999) and the National Program for Environmental Education (Programa Nacional de Educação Ambiental - ProNEA) (BRASIL, 2005). However, governments have never created a plan specific to coastal and marine zones, despite their immense strategic relevance. Efforts, therefore, have been uncoordinated and sparse, whereas a meta-evaluation of these structuring macro-policies' efficacy is inexistent. 


\section{Marine environment and biodiversity perception}

Notwithstanding, simultaneously and before environmental perception, several scientists have studied the population's perception of the sea and its organisms. The urban population's knowledge about nature is in general nearly none. According to Oliveira et al. (2009), even though most children and beachgoers often visited Boa Viagem beach in Recife, at the coast of Recife state in Northeastern Brazil, $75 \%$ of them believed corals to be vegetal.

Rua et al. (2015) have studied children's environmental perception of the sea through drawings, and realized that: a) they believed there were comparably more natural items in the sea, although there were also mermaids, especially during holiday months; b) they identified 54 items in the sea, thus considered rather rich; c) among fish species, clownfish were mentioned the most; d) sharks were not identified as fish, and always seen as angry and hostile; e) few beings, such as fish and algae, appear more often - also surprising in this case. We may conclude the sea is still a fantasy place for kids, with mermaids and angry sharks, but they could also identify the existence of marine flora - related to algae by authors. This is a good surprise in contrast with media-broadcast fantasies and prejudices towards children, which often bring more harm than benefit and thus need to be undone.

\section{Marine environmental education}

The categorization proposed by Pedrini (2010) for MEE tendencies in Brazil includes initiatives of which we mention just a few: a) involving charismatic species, such as spinner-dolphin watching, according to Silva Jr. et al. (2010); b) in ecosystems, such as coral reefs in interpretive trails, according to Rhormens et al. (2017); c) with several audiences, such as scuba-divers, according to Pedrini et al. (2010); d) with simulacra, such as in marine aquariums (GALLO NETO; BARBOSA, 2010); e) in formal basic, middle and higher education through field lessons, environment study and visitation (HADEL, 2010; OLIVEIRA, 2013); f) in non-formal education, including participation as trainees in research projects (LOPES; BOZELLI, 2004); g) in informal education, for instance in excursions, workshops, interviews, short courses etc. (PANITZ, 2010).

Other categorizations of MEE are possible. Its current incorporation by ME can be systematized along four perspectives: a) marine and coastal EE in general; b) EE in marine and coastal protected areas; c) EE developed by networks of educators or researchers, such as the Benthic Coastal Habitats Monitoring Network (Rede de Monitoramento de Habitats Bentônicos Costeiros - ReBentos); d) EE for ecotourism, implemented by the Subaquatic Trail project (Projeto Trilha Submarina - TrilhaSub) project in the Ilha Anchieta State Park, in São Paulo state. New articles are listed in a non-exhaustive way. 
Table 2: Categorization of Brazilian MEE of interest for SME (Sustainable Marine Ecotourism). Tabela 2: Categorização da Educação Ambiental Marinha de interesse para o Ecoturismo Marinho Sustentável).

\begin{tabular}{|c|c|c|c|}
\hline No & Category & Initiative (state) & Author(s) \\
\hline \multirow[t]{4}{*}{1} & \multirow{4}{*}{$\begin{array}{l}\text { Marine and coastal EE } \\
\text { in general }\end{array}$} & $\begin{array}{l}\text { Ondas Que Te Quero Mar } \\
\text { project (Rio Grande do Sul) }\end{array}$ & Crivelaro et al. (2001) \\
\hline & & $\begin{array}{l}\text { Mero do Brasil project (Santa } \\
\text { Catarina) }\end{array}$ & $\begin{array}{l}\text { Gerhardinger et al. } \\
(2010)\end{array}$ \\
\hline & & Coral Vivo project (Bahia) & $\begin{array}{l}\text { Barreira e Castro et al. } \\
(2016)\end{array}$ \\
\hline & & 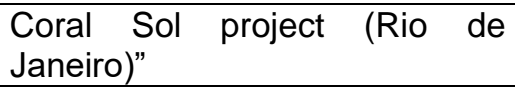 & Meireles et al. (2016) \\
\hline \multirow[t]{3}{*}{2} & \multirow{3}{*}{$\begin{array}{l}\text { EE in marine and coastal } \\
\text { protected areas }\end{array}$} & $\begin{array}{lcc}\text { EE in } & \text { Arvoredo } & \text { Marine } \\
\text { Biological } & \text { Reserve } & \text { (Santa } \\
\text { Catarina) } & & \end{array}$ & Matarezi et al. (1998) \\
\hline & & $\begin{array}{l}\text { EE in Fernando de Noronha } \\
\text { National Park (Pernambuco) }\end{array}$ & $\begin{array}{l}\text { Silva Junior et al. } \\
(2010)\end{array}$ \\
\hline & & $\begin{array}{l}\text { Representative EE projects in } \\
\text { Brazilian coastal and marine } \\
\text { protected areas }\end{array}$ & Pimentel et al. (2018) \\
\hline \multirow[t]{2}{*}{3} & \multirow{2}{*}{$\begin{array}{l}\text { EE developed by } \\
\text { networks of educators or } \\
\text { researchers networks }\end{array}$} & $\begin{array}{l}\text { A study of the Brazilian EE } \\
\text { Network (Rede Brasileira de } \\
\text { Educação Ambiental - Rebea) }\end{array}$ & Sanchez (2008) \\
\hline & & $\begin{array}{l}\text { Marine and coastal EE in the } \\
\text { context of global climate } \\
\text { change (ReBentos) }\end{array}$ & Berchez et al. (2015) \\
\hline 4 & EE for ME & $\begin{array}{l}\text { EE tests in TrilhaSub's marine } \\
\text { trail }\end{array}$ & $\begin{array}{l}\text { Pedrini et al. (2008a, } \\
\text { 2008b, 2010b) }\end{array}$ \\
\hline
\end{tabular}

\section{Coastal and marine environmental education (EE) in general}

This category is the most comprehensive - concentrating tens of activities around the country, many of which are very high level. The four selected works, originated in marine or fishing biology areas, produce not only excellent research results, but also outstanding EE outcomes with communities within its influence area, transforming people and their collectivity. Besides, their success is documented by vast literature, which enables them as representatives of Brazilian efforts. Yet, they provide a brief idea of projects currently in progress in the country. Most focus on charismatic species or icons (Meros and Coral Vivo), bioinvaders (Coral Sol) and coastal communities (Ondas Que Te Quero Mar). Despite their differences, all have very good results, increasing students' teachers' and coastal communities' knowledge about marine environments and socioenvironmental coastal issues.

\section{EE in marine and coastal protected areas}

This category also encompasses tens of examples, of which three have been selected as emblematical: a) Matarezi et al. (1998) present Arvoredo Marine Biological Reserve's EE project, in Santa Catarina; b) Silva Jr. et al. (2010) present their project, called EE Ecological Holidays in Fernando de Noronha National Park, Pernambuco; c) Pedrini et al. (2018) present significant projects in coastal and marine protected areas in Brazil, including the Aquarium of Paraíba. 


\section{EE developed by environmental educator networks such as $R E B E A$ and researcher networks such as rebentos}

\section{- The Brazilian Environmental Education Network}

Rebea is a network of networks, comprehending a theme network about coastal and marine zones, called Coastal and Marine Environmental Education Network (Rede de Educação Ambiental Costeira e Marinha REACOMar). Educators from several of the country's geographic areas who are interested in the theme gather in it. As for networks' initiatives, some dissertations and theses study Rebea and other interwoven networks (SANCHEZ, 2008). Rebea has a journal called Brazilian Environmental Education Journal (Revista Brasileira de Educação Ambiental - RevBEA), and regularly promotes the Brazilian Environmental Education Forum, hosted each time by a different city, and publishes its annals. The event always includes coastal and marine theme sessions, and its last edition counted with a roundtable about sustainable marine ecotourism (SME), details of which can be found in Rebea's website.

\section{- Benthic Coastal Habitats Monitoring Network}

ReBentos is affiliated to the Coastal Zones Sub-Network of the Climate Network in the Department for Science, Technology, Innovation and Communication, as well as to the National Institute for Climate Change Science and Technology (Instituto Nacional de Ciência e Tecnologia para Mudanças Climáticas). Its goals involve structuring scientific bases for detecting the effects of regional and global environmental change on benthic habitats.

The organization currently gathers 167 researchers from the field of coastal benthic organisms from 57 education and research institutions located in 17 different coastal Brazilian states, besides scientists from international organizations. Its structure comprises eight theme working groups: a) rhodolite beds; b) rocky coasts; c) estuaries; d) environmental education; e) sea grasses; f) mangroves and marshes; g) beaches; h) coral reefs.

The EE working group has been joining together environmental educators who are also part of other working groups. It is currently producing a volume on MEE as part of a collection about Brazilian marine biodiversity (PEDRINI 2018; PEDRINI et al. 2018; PIMENTEL et al. 2018). Lectures along the group's projects' marine trails include anthropogenic climate change (BERCHEZ et al. 2015).

\section{- Environmental education for ecotourism by the TrilhaSub project}

This item only comprehends the initiatives by the TrilhaSub project, implemented in January 2002 in the Biosciences Institute of the University of São Paulo (Universidade de São Paulo - USP). Its goals involve developing, applying and testing models for EE in marine ecosystems. It has improved with time and produced EE models for land ecosystems and virtual media, besides providing capacity-building for not only monitors, but also basic and 
high public school teachers and students (BERCHEZ et al., 2005, 2007; GHILARDI; BERCHEZ, 2010; GHILARDI-LOPES et al., 2012).

Besides training USP undergrad students, it updates public school teachers, hiring undergrad students as monitors. It encourages and supports scientists from other universities during their summer research activities at Ilha Anchieta State Park (São Paulo state) under the state government's consent. The project has been publishing scientific papers, training new marine scientists and supplying society with great service. Moreover, it has trained hundreds of students along its interpretive trails and introduced the marine environment and its organisms to thousands of people (BERCHEZ et al., 2005, 2007; GHILARDI; BERCHEZ, 2010; GHILARDI-LOPES et al., 2012).

The project produced a compilation of significance for Brazilian scientific literature, called Guide for Environmental Education in Rocky Coasts (Guia para educação ambiental em costões rochosos). The book serves several purposes by tending to marine biology, environmental education and scientific popularization (GHILARDI-LOPES et al. 2012). Other relevant chapters and papers produced by the group include Berchez et al. (2005, 2007 and 2015), Ghilardi and Berchez (2010), Ghilardi-Lopes et al. (2012) and Pedrini et al. (2014). Also, Pedrini et al. (2008, 2010) have tested EcoTurisMar's model during TrilhaSub's summer campaigns in Ilha Anchieta State Park for potential implementation in Armação dos Búzios Marine Environmental Protection Area (Rio de Janeiro state).

\section{Ecotourism and marine tourism in Brazil: a possible definition}

Table 3 reinforces the Brazilian ME concept by presenting differing traits between marine tourism and marine ecotourism in the country. Table 3 (next page) demonstrates ME to be a really sustainable form of tourism, thus earning the SME designation (GARROD et al., 2002; GARROD; WILSON, 2004).

Other ecotourism projects occurring along the Brazilian coast are selfdesignated as coastal tourism. This classification, however, lacks proper conceptualization, since the species it watches belong to marine fauna, deserving thus, according to Brazilian law, the ME designation. The Brazilian Program for Marine Turtle Conservation (Programa Brasileiro de Conservação das Tartarugas Marinhas - Tamar) is the country's largest and most important marine turtle conservation project. Its regular publications include scientific studies about the biology and conservation of the species it takes care of in its widespread posts along the entire Brazilian coast (MARCOVALDI et al., 1999). Four recent renderings of Tamar's ecotourism and marine and coastal EE are worth mentioning.

Pegas et al. (2011) and Pedrini et al. (2018) deal with the Training Program for Young Ecological Guides, which instruct 10-14-year-old children from Praia do Forte's fishing communities with knowledge about turtle biology. They later act as young tour guides for a year. The project, executed since 1995, has already trained 2,100 children and contributed to the ecotourism program. Research reports by Pegas et al. (2013) - one of the country's best project-impact analyses - on Tamar's costal ecotourism project have 
demonstrated its objective contribution to the population with which it is developed.

Table 3: Main differing traits between marine tourism and marine ecotourism in Brazil.

Tabela 3: Características principais que diferenciam o turismo e o ecoturismo marinho no Brasil.

\begin{tabular}{|c|c|c|c|}
\hline & Traits & \multicolumn{2}{|c|}{ Attributes } \\
\hline & & Marine tourism & Marine ecotourism \\
\hline 1 & Products' goal & Leisure in the sea. & $\begin{array}{l}\text { Knowing and preserving } \\
\text { marine/estuarine ecosystems and } \\
\text { species by interpreting their } \\
\text { environment. }\end{array}$ \\
\hline 2 & Profit distribution & $\begin{array}{l}\text { Concentrated on } \\
\text { enterprise's owner. }\end{array}$ & $\begin{array}{l}\text { Proportionately split between } \\
\text { operator and hosting community. }\end{array}$ \\
\hline 3 & $\begin{array}{l}\text { Technical briefing as } \\
\text { part of the product }\end{array}$ & Absent. & Present. \\
\hline 4 & $\begin{array}{l}\text { Audience/product } \\
\text { restriction }\end{array}$ & Unlimited. & Up to $20-25$ tourists. \\
\hline 5 & $\begin{array}{l}\text { Community } \\
\text { engagement }\end{array}$ & Absent. & Present. \\
\hline 6 & Interpretation/EE & Absent. & Present. \\
\hline 7 & $\begin{array}{l}\text { Negative environmental } \\
\text { impact }\end{array}$ & Unlimited. & Limited. \\
\hline 8 & $\begin{array}{l}\text { Local income } \\
\text { generation }\end{array}$ & Discretionary. & Present. \\
\hline 9 & City tax collection & Discretionary. & Present. \\
\hline 10 & Scale & Wide. & Small. \\
\hline 11 & Physical infrastructure & Large. & Nearly none. \\
\hline 12 & $\begin{array}{l}\text { Community-project } \\
\text { relationship formality }\end{array}$ & Formal. & Informal. \\
\hline 13 & $\begin{array}{l}\text { Negative sociocultural } \\
\text { transformation }\end{array}$ & Yes. & No. \\
\hline 14 & Tourist behavior & $\begin{array}{l}\text { Uninterested and } \\
\text { insensitive to local } \\
\text { culture and traditions. }\end{array}$ & $\begin{array}{l}\text { Interested and sensitive to local } \\
\text { culture and traditions. }\end{array}$ \\
\hline
\end{tabular}

[Adapted from Pimentel (2006) and Pedrini et al. (2011)]

Lima et al. (2018) report that all 160,000 ecotourists visiting Tamar's post in Fernando de Noronha archipelago in 2013-2016 preferred practical activities with marine turtles. The product called "Lecture cycle" attracted the largest demand $(76,000$ people), but the sum of "Scientific capture" $(36,000)$ with "Hatchlings release" $(41,000)$ indicate these to be ecotourists' favorite activities. They depend, however, on the species' biological cycle, whereas lectures are regularly offered on a daily basis (LIMA et al., 2018).

Barbosa and Perinotto's (2010) reveal another example of coastal ecotourism. Developed in a mangrove without diving, its product is realized along a local-guide-aided interpretive trail. Activities are based on seahorses as charismatic species, demonstrating local unsustainable fishing practices and their potential do exterminate the species from the region. In order to avoid stress, animals are kept in an aquarium where visitors may watch but not touch.

Brazilian fauna-watching (eco) tourism, especially with whales and dolphins, is approached by several interesting studies, of which two are of special interest in our case. The first is Palazzo Jr., Iñiguez and Hevia's (2004) 
inventory - an important source of information - of 80 research projects around the world dealing with whales and dolphins, indicating studies' geographical location, animal species involved, kinds of research conducted and kinds of interaction during watching. The second is Hoyt and Iñiguez's (2008) presentation of empirical data about whale and dolphin-watching ecotourism, confirming this paper's information on humpback whales and spinner dolphins.

Besides marine or estuarine fauna-observation tourism, SME in Brazil is also implemented through direct watching of biological communities along partially or entirely underwater interpretive trails (PEDRINI, 2013). The activity is generally followed by briefings at interpretive spots, aided by support interpretive materials, such as biodiversity guides (BERCHEZ et al. 2005).

\section{Marine and estuarine interpretive trails in Brazil}

SME activities along previously planned and scientifically defined routes are defined as interpretive trails (PEDRINI, 2013, 2018a, b). However, depending on the goal set by event organizers, inadequate naming happens very often. Most common examples are: a) ecotouristic trail; b) educational trail; c) sensory trail; d) adapted trail; e) pedagogical trail. Table 4 presents the list of Brazilian ecotouristic or pedagogical lecture activities in marine or estuarine interpretive trails the routes of which are partially or entirely set in the sea.

Table 4: List of studies approaching ecotouristic or pedagogical lectures in marine or estuarine interpretive trails partially or entirely set in the sea.

Tabela 4: Lista de trabalhos com trilhas interpretativas parcial ou totalmente marinhas (com sua ocorrência geográfica por estado brasileiro), sendo classificadas segundo o seu propósito (pedagógicas ou ecoturísticas).

\begin{tabular}{|c|c|c|c|}
\hline \multicolumn{2}{|c|}{ Features } & \multicolumn{2}{|c|}{ Purpose } \\
\hline Author & State & Pedagogical & Ecotouristic \\
\hline 1.Wegner (2002) & \multirow{5}{*}{ Santa Catarina } & & $\mathrm{X}$ \\
\hline 2.Wegner et al. (2004) & & & $\mathrm{X}$ \\
\hline 3.Bertuol (2005) & & & $\mathrm{X}$ \\
\hline 4.Lima et al. (2006) & & & $\mathrm{X}$ \\
\hline 5.Ayrosa (2011) & & & $\mathrm{X}$ \\
\hline 6.Berchez et al. (2005) & \multirow{7}{*}{ São Paulo } & $\mathrm{X}$ & \\
\hline 7.Berchez et al. (2007) & & $\mathrm{X}$ & \\
\hline 8.São Paulo (2008) & & & $\mathrm{X}$ \\
\hline 9.Hadel (2010) & & $\mathrm{X}$ & \\
\hline 10.Machado et al. (2010) & & $\mathrm{X}$ & \\
\hline 11.Pedrini et al. (2010b) & & & $\mathrm{X}$ \\
\hline 12.Lima et al. (2010) & & & $\mathrm{X}$ \\
\hline 13.Pedrini et al. (2011) & \multirow{5}{*}{ Rio de Janeiro } & & $\mathrm{X}$ \\
\hline 14.Pedrini et al. (2016a) & & & $\mathrm{X}$ \\
\hline 15.Meirelles et al. (2013) & & $\mathrm{X}$ & \\
\hline 16.Meirelles et al. (2016) & & $\mathrm{X}$ & \\
\hline 17.Zaú (2018) & & $\mathrm{X}$ & \\
\hline 18.Barbosa \& Perinotto (2010) & Piauí & & $\mathrm{X}$ \\
\hline 19.Rhormens et al. (2017) & Bahia & & $\mathrm{X}$ \\
\hline Total & & $7(37 \%)$ & $12(63 \%)$ \\
\hline
\end{tabular}

(based on Pedrini, 2013) 
The Table 4 leads to the conclusion that most (63\%) studies about interpretive trails mention their use as coastal or marine ecotourism. Even the ones whose pedagogical approach includes lectures can be given ecotouristic purposes in other contexts. Therefore, there is great potential for the adoption of lectures in corresponding interpretive trails along the Brazilian coast, thus starting SME activities.

\section{Marine ecotourism in Brazil}

SME occurs from the tropical to the subtropical Brazilian coast. This initiative selection includes projects which designate themselves as ME either in studies or reports considered by this literature review. Table 5 presents four of them, two of which relate to interpretive trails (EcoTurisMar and ProMar) and two to fauna watching (humpback whale and spinner dolphin).

Table 5: Emblematical ME projects in Brazil, studies featuring them and protected areas where their products are offered.

Tabela 5: Projetos emblemáticos de ecoturismo marinho no Brasil, pesquisas realizadas sobre eles e áreas protegidas onde os seus produtos são oferecidos.

\begin{tabular}{|c|l|l|l|}
\hline No & \multicolumn{1}{|c|}{$\begin{array}{c}\text { Product and ecosystem } \\
\text { features }\end{array}$} & $\begin{array}{l}\text { Project or enterprise and } \\
\text { studies featuring it }\end{array}$ & $\begin{array}{c}\text { Protected natural area / } \\
\text { State }\end{array}$ \\
\hline 1 & $\begin{array}{l}\text { Snorkeling and watching in } \\
\text { an interpretive trail along } \\
\text { rocky coast. }\end{array}$ & $\begin{array}{l}\text { EcoTurisMar project, } \\
\text { (Pedrini et al., 2011, 2014, } \\
\text { 2016a, 2016b; Pimentel et } \\
\text { al., 2018) }\end{array}$ & $\begin{array}{l}\text { Armação dos } \\
\text { Marine } \\
\text { Protection Area / Rio de } \\
\text { Janeiro }\end{array}$ \\
\hline 2 & $\begin{array}{l}\text { Snorkeling and watching in } \\
\text { an interpretive trail in the } \\
\text { sea in a coral reef } \\
\text { ecosystem. }\end{array}$ & $\begin{array}{l}\text { ProMar project, (Pedrini et } \\
\text { al., 2016a, 2018; } \\
\text { Rhormens et al., 2017) }\end{array}$ & $\begin{array}{l}\text { Environmental Protection } \\
\text { Area of Tinharé and } \\
\text { Boipeba Islands / Bahia }\end{array}$ \\
\hline 3 & $\begin{array}{l}\text { Binocular-aided humpback- } \\
\text { whale watching from boat in } \\
\text { a coral reef ecosystem. }\end{array}$ & $\begin{array}{l}\text { Humpback Whale Institute } \\
\text { (Instituto Baleia Jubarte), } \\
\text { (Aguiar \& Interaminense, } \\
\text { 2005; Barreto \& } \\
\text { Alvarenga, 2007) }\end{array}$ & $\begin{array}{l}\text { Abrolhos Marine National } \\
\text { Park / Bahia }\end{array}$ \\
\hline 4 & $\begin{array}{l}\text { Binocular-aided spinner- } \\
\text { dolphin watching from rocky } \\
\text { hill br boat. }\end{array}$ & $\begin{array}{l}\text { Spinner Dolphin project, } \\
\text { (Silva Jr., 2003, 2009; } \\
\text { Silva Jr. et al., 2010) }\end{array}$ & $\begin{array}{l}\text { Fernando de National Noronha } \\
\text { Pernambuco Park }\end{array}$ \\
\hline
\end{tabular}

Projects involving ME interpretive trails will be object of following section's case study, and therefore not approached here. This section presents details of fauna-watching tourism projects defined in Brazil as ecotourism - a kind of project which has globally moved US\$ 1 million, according to Andrade (2006). This fact exemplarily supports the conservation of target species, fostering the implementation of SME along with existing supporting legal corpus. The amount of tourists engaged with this kind of ecotourism is also massive: O'Cornor et al. (2009) estimate ca. 130,000 yearly ecotourists have watched dolphins along the coast from Bahia to Santa Catarina states, complemented by Fernando de Noronha's 70,000. The authors also estimate around 229,000 ecotourists watched whales along the 
Brazilian coast, which represented $2 \%$ of the global number in 2008 . Brazil, therefore, already has a large-scale contribution to this kind of ecotourism.

Humpback whales are one of the most beloved charismatic species in the Brazilian coast [PALAZZO Jr. and BOTH (1988)]. Aguiar and Interaminense (2005) and Barreto and Alvarenga (2007) provide important information about them. Whale-watching tourism was regulated by the Brazilian Institute for the Environment and Renewable Natural Resources (Instituto Brasileiro do Meio Ambiente e dos Recursos Naturais Renováveis Ibama) in Order 117/1996, later updated by other orders to prevent animal disturbance. This way, watching whales in the sea as part of an ecotourism product is easily viable. Its realization in a region close to Abrolhos National Marine Park hosts ca. 12,000 yearly visitors (FONSECA et al., 1997), a touristic flow especially present in Caravelas do Sul, a city in Southern Bahia whose livelihood essentially relies on whale-watching (eco)tourism.

According to Andrade (2006), the Right Whale Institute (Instituto Baleia Franca) had the potential to develop ecological tourism at the time of their study's publication. No updated bibliographical data about that process are currently available, however, except for an empirical study on the use of charismatic species by fauna-watching touristic products, such as right whales and manatees, which provides an overview of the activity. Recently, NGOs engaged with sea conservation have fought this kind of SME, especially against some embarked-tour operators. Surveillance institutions, probably deprived of boats, are unable to implement constant and expensive sea monitoring. This kind of tourism, therefore, should require business people to be trained in EE.

According to Silva Jr. (2009), ME is already implemented in Fernando de Noronha archipelago, where spinner-dolphin watching is one of the main attractions. In 2006, Ibama reported 2,261 touristic boat rides aimed at watching dolphins in the national park, amounting to 85,000 visitors. Each tour lasts for about three hours, and tourists spends ca. US\$300 per night on inns, of which boat rides cost 5\% (US\$15) (SILVA JR., 2009). Dolphin-watching sea tour operators, therefore, have daily made US $\$ 1,275,000$. Since 136,361 spinner dolphins have entered Dolphins Bay that year, each of them accounts for US\$ 7.8 added to the local economy. This form of ME appears to be the one best structured in the archipelago. An empirical study of the way the country's current crisis affects the activity is still lacking, however.

Besides ecotourists interested in watching turtles, spinner dolphins and humpback whales, Fernando de Noronha also attracts common sun-andbeach visitors. The Pernambuco state government, responsible for managing the archipelago, has adopted control measures which take into consideration its carrying capacity. However, since daily numbers may reach 20 boats and ca. 1, 5000 people, many researchers are concerned with tourists' potentially negative impacts. Lima (2000), for instance, an officer in one of Pernambuco state's environmental control institutions, is the author of several inquiries concerned with overcoming the obstacles currently on the way to perfectly managing (eco) tourism. 


\section{Case study: EcoTurisMar and ProMar's models for ME interpretive trails}

Deeper scrutiny of EcoTurisMar and ProMar projects, both of which this author has led and participated in creating (PEDRINI et al., 2011, 2016a, 2016b, 2018; PEDRINI 2017; RHORMENS et al. 2017) reveals that the latter, designed after the former, still shares $80 \%$ of its traits with its model-project, as indicated by the comparison of both initiatives' twenty most important phases (Table 6). The only differences happened during lectures in coral reef trails.

\section{EcoTurisMar's sustainable marine ecotourism model}

EcoTurisMar's SME-product standards (PEDRINI et al., 2011, 2016a, 2016b, 2018; PEDRINI 2017; PIMENTEL et al., 2018) were conceived and planned during an emancipatory environmental education process directed at a local caiçara and fishing community oppressed by capital and destructive fishing practices. At the time of its inception, Armação dos Búzios city was about to establish the Armação dos Búzios Marine Environmental Protection Area, which would comprehend the city's entire area and engage protecting guards. Local cost of living is very high due to a majority of Argentinian and Chilean tourists arriving from their countries in charter flights, as well as to lowbuying-power tourists in cruise ships. About four ships were docked on a daily basis, carrying thousands of previously fed tourists who did not occupy the city's hotels but rather bought key rings and t-shirts, leaving only personal excrements and garbage as compensation (PEDRINI et al., 2011, 2016b). Fishermen and caicaras were deprived of their distinguishing characteristics, having sold their humble seashore houses to new rich inhabitants, who built small palaces on the sand, and moved into shacks in the city's periphery, far from the sea, after spending all the money earned with the sale. Some managed to keep their houses and started making a living out of them by selling snacks to tourists (PEDRINI et al., 2016a).

EcoTurisMar's design was preceded by an inventory of marine icthyofauna and benthic flora and fauna, while an underwater trail was established from João Fernandes (Figure 1) to João Fernandinho beaches. In order to better explain the relations between local organisms to tourists, a contextual trophic web was produced (PEDRINI et al., 2011). Meanwhile, local-trade relevant stakeholders were identified and contacted. Ville de la Plage inn, for instance, provided the project with full support. The company has been awarded several corporate certificates and prizes, such as Trip Advisor's Certificate of Excellence and NBR 15401 (MATOS, 2014). Despite the creation of the environmental protection area in the context of a dehumanized city, a spoilt-nature shore area and all recommendations against the development of an ME product, the team insisted, hoping to brake with local marine devastation. Nevertheless, local trade's unconcern, along with lacking support from other stakeholders and governmental programs for the creation of socioenvironmentally sustainable touristic products. 


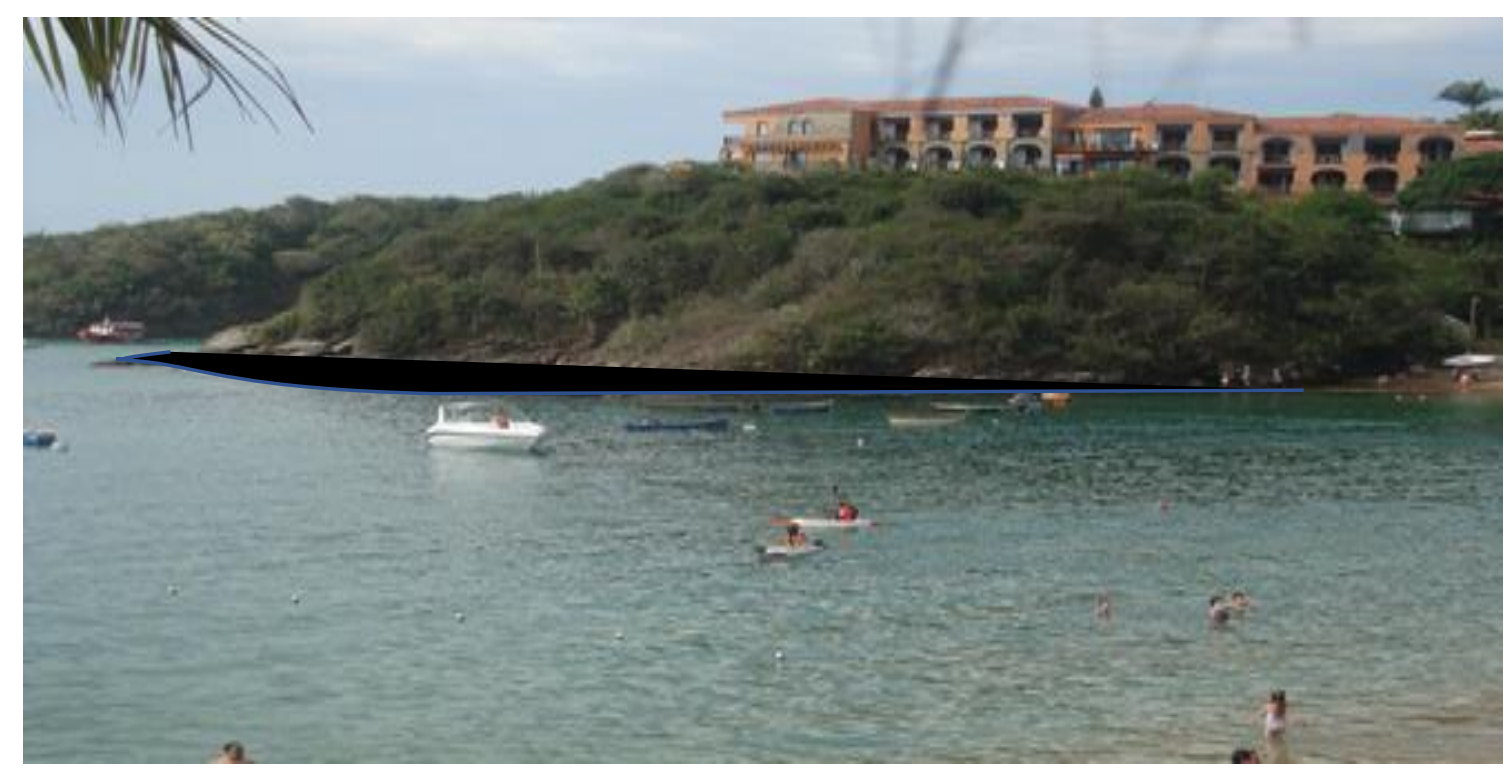

Figure 1: Rocky coast and EcoTurisMar's underwater interpretive trail (in black) in Armação dos Búzios Marine Environmental Protection Area, Rio de Janeiro state, Brazil (Credit Alexandre de Gusmão Pedrini.)

Figura 1: Costão rochoso com a área da trilha interpretativa submarina (em negrito) do Projeto EcoTurisMar na Área de Proteção Ambiental Marinha de Armação de Búzios, Estado do Rio de Janeiro, Brasil. (Crédito - Alexandre de Gusmão Pedrini.)

\section{ProMar's sustainable marine ecotourism model}

ProMar's conception and planning also happened in a context of a transformative environmental education process (PEDRINI et al., 2016b, 2018; RHORMENS et al., 2017). It was based, however, on EcoTurisMar's model (PEDRINI et al., 2011, 2016a, 2016b, 2017) and directed at a local community of caiçaras and fishermen who still live out of fishing. The project developed a model for reef ecosystem ME in the Tinharé and Boipeba Environmental Protection Area, on the Northeastern coast of Brazil. Contrasting with Armação dos Búzios, located in subtropical Rio de Janeiro, ProMar was set in warmer-sea tropical Bahia, and its trail covered shallower and calmer waters in what concerns wave rhythm. It is harder to access the area, however, which still retains preserved natural characteristics. Fishermen and caiçaras also maintain their characteristics and live near the sea.

A 300-meter-long interpretive trail was established at Tassimirim beach, habitat to very diverse coral reefs, as well as rich marine fauna and flora (Figure 2). Caiçaras were trained to act as ProMar's product's conductors, and about $90 \%$ participants evaluated its SME product as excellent. Asked if they would pay US $\$ 17-33$ for the product, $76 \%$ of tourists said yes. Among entrepreneurs and locals, $79 \%$ also rated the initiative as excellent. Every ten days, the product generates US\$ 443. Content taught during the interpretive trail was considered satisfactory, leading to the conclusion it is an adequate product. 


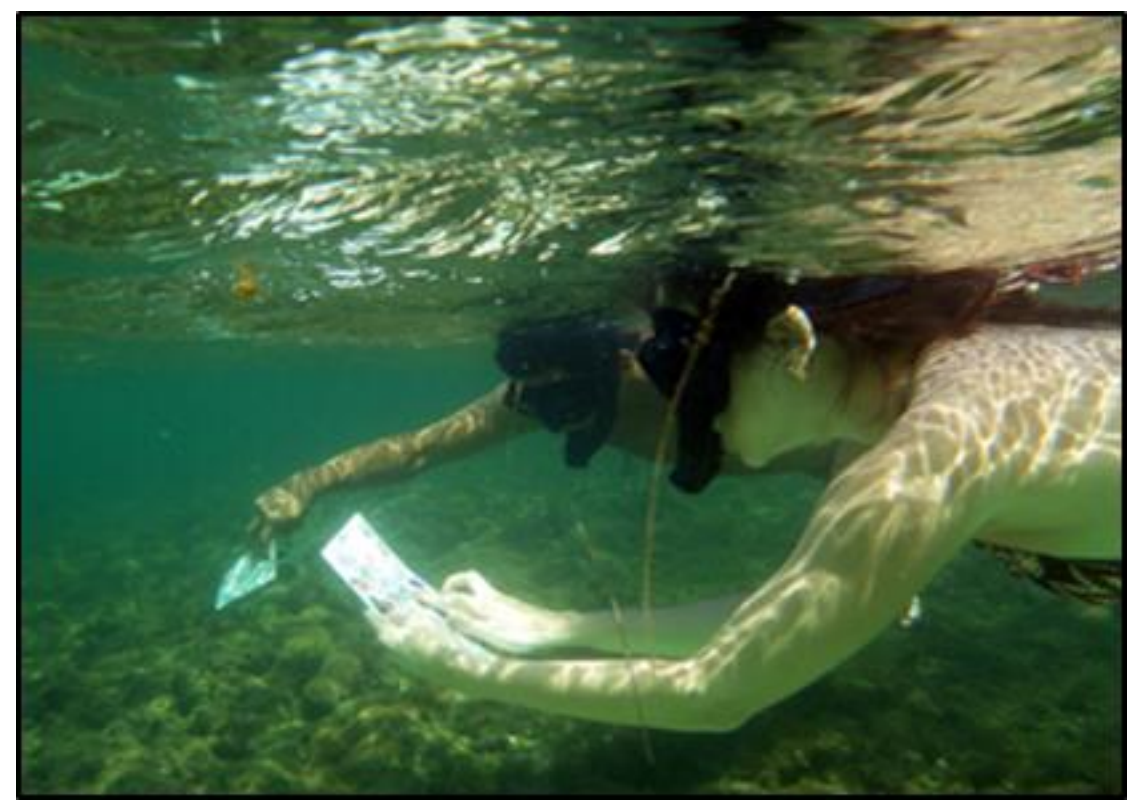

Figure 2: Snorkelers in ProMar's interpretive marine trail in Environmental Protection Area of Tinharé and Boipeba Islands (Credit - Marta Smith Rhormens).

Figura 2: "Snorkelers" na trilha interpretativa marinha do produto ProMar da Área de Proteção Ambiental das Ilhas de Tinharé e Boipeba no Estado da Bahia. (Crédito - Marta Smith Rhormens);

However, just as in EcoTurisMar, businesspeople initially committed to adopting the product changed their mind after realizing how little profit they would make, and maintained mainstream mass marine tourism. They would only adopt it if forced by the government. Despite facing the same challenges identified in EcoTurisMar, ProMar is still operating at weekends for as long as conditions allow.

Table 6 (next page) indicates that more than $80 \%$ of both projects' products' characteristics coincide. Differences occurred in very specific and contextual aspects, which made the product - namely ProMar - more adequate to its setting.

The main difference between ProMar's product and EcoTurisMar lies in technical and economic implementation viability. ProMar's model (RHORMENS et al., 2017) currently generates income, however seldom. EcoTurisMar's model (PEDRINI et al., 2011; 2016a; 2016b) generated income only during the product's experimental research period. One of its greatest advantages was the research team's boldness in creating an ME project within a refractory, discouraging and uninterested business environment. Businesses are only interested in very profitable mass tourism, even though it informs trampling (and disease) or removal (and killing) of marine organisms by tourists (TUNALA et al., 2013). However, the team was able to overcome funding obstacles, assisted by the university, Ville La Plage inn and the city government, thus planning the research project and designing EcoTurisMar's ME product, upon which ProMar's model was based (PEDRINI et al., 2011; 2016a; 2016b; 2018; PEDRINI, 2017; RHORMENS et al., 2017; PIMENTEL et al., 2018). 
Table 6: Main traits of ProMar's and EcoTurisMar's ME product models. Tabela 6: Características principais dos modelos de produtos de ecoturismo marinho EcoTurisMar e ProMar.

\begin{tabular}{|c|c|c|c|c|c|}
\hline \multirow{3}{*}{ Main traits of ecotouristic products } & \multicolumn{4}{|c|}{ Models } & \multirow[t]{3}{*}{ Observations } \\
\hline & \multicolumn{2}{|c|}{$\begin{array}{l}\text { EcoTuRis } \\
\text { Mar } \\
\text { (ETM) }\end{array}$} & \multicolumn{2}{|c|}{$\begin{array}{l}\text { ProMar } \\
\text { (PM) }\end{array}$} & \\
\hline & $Y$ & $N$ & $Y$ & $N$ & \\
\hline $\begin{array}{l}\text { 1. Previous evaluation of tourists/beachgoers' } \\
\text { negative impact on local marine biological } \\
\text { communities }\end{array}$ & $\mathrm{X}$ & & $\mathrm{X}$ & & \\
\hline 2. Potential demand evaluation & & $\mathrm{X}$ & $\mathrm{X}$ & & $\begin{array}{l}\text { No } r \text { budget } \\
\text { available in } \\
\text { ETM. }\end{array}$ \\
\hline 3. Stakeholders identification & $\mathrm{X}$ & & $\mathrm{X}$ & & \\
\hline 4. Development of local partners network & $\mathrm{X}$ & & $\mathrm{X}$ & & \\
\hline 5. Devising of stakeholder compensation & $\mathrm{X}$ & & $\mathrm{X}$ & & \\
\hline $\begin{array}{l}\text { 6. Caiçaras and fishermen association } \\
\text { engagement }\end{array}$ & & $\mathrm{X}$ & $\mathrm{X}$ & & $\begin{array}{l}\text { Fishermen in } \\
\text { ETM lived in the } \\
\text { city's periphery, } \\
\text { but the project } \\
\text { kept contact } \\
\text { with their } \\
\text { association's } \\
\text { president. }\end{array}$ \\
\hline 7. Local businesspeople engagement & $\mathrm{X}$ & & $\mathrm{X}$ & & \\
\hline 8. Local government engagement & $\mathrm{X}$ & & $\mathrm{X}$ & & \\
\hline $\begin{array}{l}\text { 9. Information availability on marine biodiversity } \\
\text { taxonomy }\end{array}$ & $\mathrm{X}$ & & $\mathrm{X}$ & & \\
\hline $\begin{array}{l}\text { 10. Development of trail's and interpretive spots' } \\
\text { site selection criteria }\end{array}$ & $\mathrm{X}$ & & $\mathrm{X}$ & & \\
\hline 11. Construction of contextual trophic web & $\mathrm{X}$ & & $\mathrm{X}$ & & \\
\hline $\begin{array}{l}\text { 12. Construction and usage of floating raft from } \\
\text { reusable PET material }\end{array}$ & $\mathrm{X}$ & & & $\mathrm{X}$ & $\begin{array}{l}\text { PM adopted } \\
\text { pool noodles } \\
\text { since the sea } \\
\text { was calm and } \\
\text { shallow. }\end{array}$ \\
\hline $\begin{array}{l}\text { 13. Fixed interpretive trail from one beach to an } \\
\text { adjacent beach }\end{array}$ & $\mathrm{X}$ & & $\mathrm{X}$ & & \\
\hline $\begin{array}{l}\text { 14. Construction of plastic-coated photographic } \\
\text { guide about the trail's marine biodiversity }\end{array}$ & $\mathrm{X}$ & & & $\mathrm{X}$ & $\begin{array}{l}\text { PM adopted } \\
\text { another project's } \\
\text { PVC board. }\end{array}$ \\
\hline 15. Lecture in interpretive points & $\mathrm{X}$ & & & $\mathrm{X}$ & $\begin{array}{l}\text { PM lectured } \\
\text { along the entire } \\
\text { route. }\end{array}$ \\
\hline 16. Pricing & $\mathrm{X}$ & & $\mathrm{X}$ & & \\
\hline $\begin{array}{l}\text { 17. Study of three main stakeholders' } \\
\text { environmental perception: a) businesspeople, b) } \\
\text { tourists, c) local residents }\end{array}$ & $\mathrm{X}$ & & $\mathrm{X}$ & & \\
\hline $\begin{array}{l}\text { 18. Training residents as potential guides, } \\
\text { conductors or small entrepreneurs }\end{array}$ & $\mathrm{X}$ & & $\mathrm{X}$ & & \\
\hline 19. Previous test with cash payment & $\mathrm{X}$ & & $\mathrm{X}$ & & \\
\hline 20. Project's continuation & & $\mathrm{X}$ & $\mathrm{X}$ & & \\
\hline Total & 17 & 3 & 17 & 3 & \\
\hline
\end{tabular}

(based on Pedrini et al. 2016b) 
ProMar's product was priced at US\$16.00, although $76 \%$ of the tourists stated their preference for US\$17.00-33.00. During summer's high season, this price produced US $\$ 433.00$ in ten days, which enabled the project to buy more equipment and hire more staff, lowering its costs and thus being able to increase trade. Monthly costs were at ca. US\$1,300.00 - slightly over similar local marine touristic products' average (US\$ 1,200.00) (RHORMENS et al., 2017). Costs hampered the product's broad implementation - whose rights are public - by lower buying power caiçaras acting as small entrepreneurs. Potential solutions to this issue include government-subsidized loans or organizing caiçaras in cooperatives. However, ProMar's is a reasonable cost to be undertaken by the NGO and businessmen in the sector, despite lower profits in comparison with mainstream marine tourism.

\section{Main challenges}

1. Lack of governmental funding for the development of sustainable marine (and estuarine) ecotouristic products.

2. Absence of laws making it mandatory for tour operators to offer sustainable marine ecotouristic products inside and around protected areas.

3. Higher costs of marine ecotouristic products in comparison with mainstream touristic products.

4. Local traders' lack of interest in undertaking sustainable marine ecotouristic products.

5. Funding and general choice for environmentally damaging mainstream touristic products.

6. Lack of low-interest public funding for community-based ecotouristic enterprises.

7. Governmental divestment from public universities - and thus from faculty's enterprises in partnership with coastal caiçaras communities.

8. Dismantling of socioenvironmental governmental agencies liable for control and surveillance, especially in relation to marine fauna-watching ecotourism.

\section{Conclusion}

This review aimed at providing an overview of the situation of $\mathrm{ME}$ projects currently developed in Brazil through a bibliographical analysis. ME, which historically stemmed from MEE projects mainly implemented by universities, NGOs and few public institutions, is still incipient. ME through marine interpretive trails draws from two projects: EcoTurisMar and ProMar. The former, conducted by Rio de Janeiro State University (Universidade do Estado do Rio de Janeiro), is partially based on MEE TrilhaSub, by São Paulo State University. 
As far as ecotourism involving marine fauna watching with marine dolphins and whales is concerned, governments ought to provide infrastructure and staff to enhance surveillance over tour operators' boats. As for ME in interpretive trails, it is still in early development, and its regulation is not urgent.

A broad establishment of SME in the country should require marine protected areas to include these kinds of project, in association with traditional or fishermen communities, so as to provide them with income and avoid their migration to big cities.

Another urgent need refers to the realization of research including visits to typical ME projects in the Brazilian coast, so as to determine their actual situation: which ones are operational, what their peculiarities, strengths and weaknesses are. To be sure, their managers and clients will have claims to be forwarded to governmental agencies requiring not only legal regulation, but also overcoming the challenges identified on the way to their commercial implementation.

Doubtlessly, $\mathrm{ME}$ is one of the immediate solutions that can generate income for traditional communities living in Brazil's immense coast, because it can also enhance tax collection without degrading socioenvironmental natural goods and services.

\section{Acknowledgments}

To Professor Josimar Ribeiro de Almeida (PhD), from Rio de Janeiro Federal University and Rio de Janeiro State University and Gilson Volpato (PhD) for your friendship, to my friend and laboratory colleague Daniel Shimada Brotto (PhD) for proofreading my manuscript, my wife Rosana Nunes Pedrini for your love and Jun Shimada for translating it into English.

\section{References}

AGUIAR, C.K; INTERAMINENSE L. Instituto Baleia Jubarte: Programa de Educação e Informação Ambiental (Caravelas, Ba). In: JUNQUEIRA, V.; NEIMAN, Z. (Org.) Educação Ambiental e Conservação da Biodiversidade. Barueri: Manole, 2007, p. 139-163.

AMARAL, F.M.D. DO; SANTOS, M.F.; MELO, K.V.; FRAGA, C.F.O.; OLIVEIRA, G.F.; STEINER, A.Q.; PEDRINI, A.G. The role of environmental education in changing school students' perceptions of and attitudes toward coral reefs in the Fernando de Noronha Archipelago, Brazil. Revista da Gestão Costeira Integrada, Faro, 14: 1-8, 2014; disponível em: http://www.aprh.pt/rgci/pdf/rgci-513 Amaral.pdf, acesso em: 30.03.2018.

ANDRADE, R. Brazil: Marine Protection: our challenges and conquests. São Paulo: Empresa das Artes, 2006,180 p.

ANTUNES, D.M.M.; RABINOVICI, A. Ética e Ecoturismo. In: ZYSMAN, N., RABINOVICI, A. (Ed.) Turismo e Meio Ambiente no Brasil. Barueri: Manole, 2010, p. 304-323. 
AYROSA, C. R. Trilhas subaquáticas guiadas: uma alternativa sustentável para a conservação do ambiente marinho. Estudo de caso da llha do Campeche, Florianópolis/SC. In: CONGRESSO DE ECOLOGIA DO BRASIL, 10., Anais....: São Lourenço, Brasil, SEB, 16-22 de setembro de 2011, p.12.(CD-ROM)

BARBOSA, A.G.P.; PERINOTTO, A.R.C. Trilha Ecológica do Cavalo-Marinho: Ecoturismo em Barra Grande. Rosa dos Ventos, v.19, n.1, p. 45-55, 2010.

BARREIRA E CASTRO, C.; PIRES, D. DE O.; GOUVEIA, M.T. DE J.; PEREIRA, C.M.; CALDERON, E.M.; ANSELMO, M.R. Mergulhando no Coral Vivo. Rio de Janeiro: Museu Nacional, 2016, 360 p.

BARRETO, K.D.M.; ALVARENGA, L. D.A. A Avaliação do turismo de observação de Baleias Jubarte Megaptera novaeangliae na Praia do ForteBahia, como ferramenta de Educação Ambiental. In: CONGRESSO NACIONAL DE ECOTURISMO, 6., Anais..., 2007, Itatiaia, 11 p.(CD-ROM)

BAUDE, J.L.; BLOUET, S.; GRANDRIVE, R.D.D.; JOURDAN, E.; PIANTE, C. Underwater Trails Handbook. Marseille: Medpan North Project/Wwf France, 2012, 80 p; disponível em: http://Ecorem.Fr/Reseaumer/Wakka.Php?Wiki =Guidestechniques/Download\&File=Underwater Trail Handbook.Pdf; acess in: 30.01.2015

BEARD, C. et al. Turismo de aventura: conceitos e estudos de caso. Rio de Janeiro: Elsevier, 2003.

BERCHEZ F., CARVALHAL, F.; ROBIM, M.J. Underwater interpretative trail guidance in improve education and decrease ecological damage. International Journal of Environment and Sustainable Development, Genebra, v.4, n. 2, p. 128-139, 2005; disponible em: http://www.inderscience.com/info/ inarticle.php? artid=7235 acess in: 20.10.2015.

BERCHEZ, F.; GHILARDI, N.; ROBIM, M.J.; PEDRINI, A. G.; HADEL, V.F.; FLUKIGER, G.; SIMÕES, M.; MAZZARO, R.; KLAUSENER, C.; SANCHES, C.; BESPALEC, P. Projeto trilha Subaquática - Sugestão de diretrizes para a criação de modelos de Educação Ambiental para ecossistemas marinhos. OLAM -Ciência e Tecnologia-, Rio Claro (SP), v. 7, n. 3, p. 81-208, 2007; disponível em: http://www.periodicos.rc.biblioteca.unesp.br/index.php/olam/article/view/901 ccess in: 01/07/2011.

BERCHEZ, F.A.Z.; GHILARDI-LOPES, N.P.; CORREIA, M.D.; SOVIERZOSKI, H.H.; PEDRINI, A. G.; URSI, S.; KREMER, L.P.; ALMEIDA, R. DE; SCHAEFFER-NOVELLI, Y.; MARQUES, V; BROTTO, D. S. Marine and coastal environmental education in the context of global climate changes - synthesis and subsidies for ReBentos (Coastal Benthic Habitats Monitoring Network). Brazilian Journal of Oceanography, São Paulo, v. 64, p. 137-156, 2015; disponível em: http://www.scielo.br/scielo.php?script=sci issuetoc\&pid=1679875920160006\& Ing=en\&nrm=is, acesso em: 30.03.2018. 
BERTUOL, P.R.K. Efeitos de atividades de Mergulho Autônomo sobre um ambiente de Costão Rochoso. 2005. Dissertação (Mestrado em Ciências e Tecnologia Ambiental). Universidade do Vale do Itajaí, Centro de Ciências Tecnológicas, da Terra e do Mar, Itajaí, 2005.

BRASIL. Lei Federal 6981. Política Nacional do Meio Ambiente. 1981.

BRASIL. Lei Federal № 7.661. Institui o Plano Nacional de Gerenciamento Costeiro e dá outras providências, 1988. Disponível em: http://legislacao.planalto.gov.br/legisla/legislacao.nsf/Viw Identificacao/lei\%20 7.661-1988?; acess in: 12/03/2018.

BRASIL. Lei Federal 8078, institui o Código Nacional do Consumidor. 1990

BRASIL. Diretrizes para uma Política Nacional do Ecoturismo. Brasília: Ministério da Ind. Com. e Turismo - MICT; Ministério do Meio Ambiente. 1994

BRASII. Institui a Política Nacional de Educação Ambiental - PNEA. Lei Federal no 9.795. Brasília: Ministério do Meio Ambiente. 1999

BRASIL. Ecoturismo: visitar para conservar e desenvolver a Amazônia. Brasília: MMA/SCA/PROECOTUR, 2002a, 52p.

BRASIL. Sistema Nacional de Unidade de Conservação da Natureza SNUC, Lei n.9.985 de 18 de julho de 2000. Brasília-DF: IBAMA. 2002b, 35 p.

BRASIL. Programa Nacional de Educação Ambiental (ProNEA, versão 2004). Brasília: MMA, 2005,102 p.

BRASIL. Projeto Vivências Brasil: Aprendendo com as Boas Práticas Relatório de visita técnica em Fernando de Noronha: Ecoturismo em Mergulho, 2006, 59 p. Disponível em: http://www.excelenciaemturismo.gov.br, acesso em: 07/03/2018.

BRASIL. Plano Nacional de Turismo 2007/2010: Uma viagem de Inclusão. Brasília: Ministério do Turismo, 2007.

BRASIL/Ministério do Turismo. Ecoturismo: orientações básicas. Ministério do Turismo, Secretaria Nacional de Políticas de Turismo, Departamento de Estruturação, Articulação e Ordenamento Turístico, Coordenação Geral de Segmentação. 2. ed. Brasília: Ministério do Turismo, 2010, 90 p; disponível em: http://www.turismo.gov.br. Acesso em: 12/03/2015.

BRASIL. Plano Nacional do Turismo. 2013-2016. Brasília: Ministério do Turismo. 2013.

BRASIL. IV Plano de Ação Federal para a Zona Costeira. Brasília: Ministério da Defesa. 2017.

CALADO, J. F. Impactos do Mergulho Recreativo em Ambientes Recifais do Brasil. 2018. 252 f. Tese (Doutorado em Ecologia), Universidade Federal do Rio Grande do Norte, Natal, 2018.

CHAKRAVARTY, P. In: GARROD, B.; WILSON, J.C. (Ed.) Marine ecotourism: Issues and Experiences. Channel View Publications, Clevedon, 2003, p.177-197. 
CORIOLANO, L.N.M.T. Bases Conceituais do Desenvolvimento e do Ecoturismo. In: QUEIROZ, O. T. (Org.) Turismo e Ambiente; Temas Emergentes. Campinas: Alínea, 2003, p. 11-48.

CRIVELLARO, C.V.; NETO, R.M.; RACHE, R.P. Ondas que te quero mar: educação ambiental para comunidades costeiras: Mentalidade Marítima. Porto Alegre: Gestal/NEMA, 2001.

DIEGUES, A.C.S. Human populations and coastal wetlands: conservation and management in Brazil. Ocean and Coastal Management, v. 42, p.187-210, 1999.

EDYVANE, K.; MCWILLIAM, A.; QUINTAS, J.; TURNER, A.; PENNY, S.; TEIXEIRA, I.; PEREIRA, C.; TIBIRICA, Y.; BIRTLES, A. Coastal \& Marine Ecotourism Values, Issues \& Opportunities on the North Coast of Timor Leste - Final Report. Ministry of Agriculture \& Fisheries, National Directorate of Tourism, Government of Timor Leste, 2009, $80 \mathrm{p}$.

EMBRATUR/INSTITUTO DE ECOTURISMO DO BRASIL. Ecoturismo no Brasil. 1999.

FENNEL, D.A. Ecotourism: An Introduction. London: Routledge. 1998.

FONSECA, G.A.B.; PINTO, L.P.S.; RYLANDS, A.B. Biodiversidade e unidades de conservação. In: CONGRESSO BRASILEIRO DE UNIDADES DE CONSERVAÇÃO, 1, Anais... p. 189-209. v. 1, Curitiba, 15 a 23 de novembro de 1997. Universidade Livre do Meio Ambiente, Rede PróUnidades de Conservação \& Instituto Ambiental do Paraná, Curitiba. (CDROM)

FORESTELL, P.H. If Leviathan has a Face, Does Gaia Have a Soul? Incorporatin Environmental Education in Marine Eco-tourism Programs. Ocean \& Coastal Management, v. 20, p. 267-282,1993; disponível em: https://www.sciencedirect.com/science/article/pii/096456919390070F; acesso in: 30.03.2018.

FREIRE, P. Pedagogia da autonomia: saberes necessários à prática

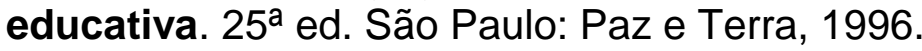

FREIRE, P. Educação como Pratica de liberdade. $23^{\mathrm{a}}$ ed. Rio de Janeiro: Paz e Terra, 1999.

FURLAN, A.S. Ecoturismo: do sujeito ao consumidor da natureza. In: RODRIGUES, A. B. (Org.) Ecoturismo no Brasil: possibilidades e limites. São Paulo: Contexto, 2003, p. 47-58.

GALLO NETO, H.; BARBOSA, C.B. Educação Ambiental em Aquários de Visitação Pública: A Experiência do Aquário de Ubatuba. In: PEDRINI, A. G. (Org.). Educação Ambiental Marinha e Costeira no Brasil. Rio de Janeiro: Eduerj, 2010, p. 227-242.

GARROD, B.; WILSON, J.C. Nature on the Edge? Marine ecotourism in peripheral coastal areas. J. Sustain. Tourism, v. 12, p. 95-120, 2004. 
GARROD, B.; WILSON, J. C.; BRUCE, D. Ecoturismo Marino Genuinamente Sostenible en el Area Atlantica de la UE: Guía de Buenas Practicas. Bristol: University of the Weast of England, 2002.

GARROD, B.; WILSON, J.C.; BRUCE, D.M. Defining marine ecotourism: a delphi study. In: GARROD, B.; WILSON, J.C. (Ed.) Marine ecotourism: Issues and Experiences. Clevedon: Channel View Publications, 2003, p. 1736.

GERHARDINGER, L.C.; BORGONHA, M.; BERTONCINI, A. A. Memórias do Mar: biodiversidade, conservação e cultura no litoral brasileiro. Florianópolis: Ecomares, 2010,164 p.

GHILARDI-LOPES, N.P.; BERCHEZ, F. Projeto Trilha Subaquática - modelos de educação ambiental marinha para o grande público. In: PEDRINI, A. G. (Ed.). Educação ambiental marinha e costeira no Brasil. Rio de Janeiro: EdUERJ, 2010, p. 71-91.

GHILARDI-LOPES, N.P.; HADEL, V.F.; BERCHEZ, F. Guia para Educação Ambiental em Costões Rochosos. Porto Alegre: Artmed, 2012, 200 p.

GHILARDI-LOPES, N.P.; TURRA, A.; BUCKERIDGE, M.S.; SILVA, A.C.; BERCHEZ, F.A.D.S.; OLIVEIRA, V.M.D. On the perceptions and conceptions of tourists with regard to global environmental changes and their consequences for coastal and marine environments: A case study of the northern São Paulo state coast, Brazil. Marine Policy v.57, p. 85-92. 2015.

GOMES, P.M. (Eco)Turismo uma (Re) Leitura dos Discursos. Brasília: IBAMA, 2003,111 p.

HADEL, V.F. Programa de Visitas ao Centro de Biologia Marinha-USP: o monitor na mediação entre a Academia e o grande público. In: PEDRINI, A. G. (Org.) Educação Ambiental Marinha e Costeira no Brasil. Rio de Janeiro: Eduerj, 2010, p. 93-114.

HANNAK, J.S.; KOMPATSCHER, S.; STACHOWITSCH, M.; HERLER, J. Snorkelling and trampling in shallow-water fringing reefs: Risk assessment and proposed management strategy. Journal of Environmental Management, v. 92, p. 2723-2733, 2011.

HOYT, E.; INIÍGUEZ, M. The State of Whale Watching In Latin America. Wdcs, Chippenham, Uk; Ifaw, Yarmouth Port, USA and Global Ocean, London, 2008, $60 \mathrm{p}$.

IBAMA. Portaria $n^{\circ} 117 / 1996$ regulamenta o turismo de observação de baleia jubarte no Brasil. 1996.

KINKER, S. Ecoturismo e conservação da natureza em parques nacionais. Campinas: Papirus, 2005, 224 p.

KITZMANN, D.; ASMUS, M. Gestão costeira no Brasil: estado atual e perspectivas. Montevideo: Ecoplata, 2004, 45 p. 
LIMA, M.L.F. DA C. Arquipélago de Fernando de Noronha: uma avaliação dos conflitos entre a demanda turística e os objetivos de conservação da natureza. In: RODRIGUES, B.A. (Org.) Turismo e Ambiente: Reflexões e Propostas. 2 ed. São Paulo: Hucitec, 2000, p.138-148.

LIMA, L.P.Q.; DUTRA-NETO, L.; HOLANDA, L.A. Programa de Ecoturismo e Educação Ambiental do Projeto TAMAR - Fernando de Noronha: uma análise de 2013 a 2016. Revista Brasileira de Ecoturismo, São Paulo, v.11, n. 1, p.47-60. fev/abr,2018.

LIMA, M.L.P.; SCHMIDT, A.; CHAMAS, C.C.; WEGNER, E. Implantação de Trilhas Subaquáticas Guiadas na Ilha do Campeche, Florianópolis-Sc. In: ENCONTRO NACIONAL DE GERENCIAMENTO COSTEIRO, 1., Anais..., Florianópolis, Agência Brasileira de Gerenciamento Costeiro, 2010, 4 p. (CDROM)

LIMA, M.L.P.; SCHMIDT, A.; DIDOMENICO, M. Implantação de trilha subaquáticas guiadas em Picinguaba, Ubatuba, SP. In: CONGRESSO BRASILEIRO DE OCEANOGRAFIA, 3., Anais..., Rio Grande (RS), AOCEANO,17-21 de maio de 2010, p. 32-34.(CD-ROM).

LOPES, A. F.; BOZELLI, R.L. Os Primeiros Passos da Educação Ambiental em um Projeto de Pesquisas ecológicas de Longa Duração: Reflexão sobre um Caso. In: ROCHA, C.F.D. DA; ESTEVES, F. DE A.; SCARANO, F.R. (Org.) Pesquisas de Longa Duração na Restinga de Jurubatiba; Ecologia, História Natural e Conservação. São Carlos: RiMa, 2004, p. 353-360.

LOUREIRO, C. F. DE (Org.) Educação Ambiental, Gestão Pública, Movimentos Locais e Formação Humana: uma abordagem emancipatória. São Carlos: RiMa, 2009, 167 p.

MACHADO, G.E.M.; NASSAR, C.A.G.; PEDRINI, A. DE G. Implantação de Trilhas Subaquáticas para uso em Educação Ambiental nas Unidades de Conservação. In: PEDRINI, A.G. (Org.) Educação Ambiental Marinha e Costeira no Brasil. Rio Janeiro: EdUERJ, 2010, p.33-50.

MMA. MACRODiagnóstico da Zona Costeira e Marinha do Brasil. Brasília: MMA, 2008, 242 p.

MATAREZI, J.; COUTINHO, A.K.; NEVES E SILVA, L.; FIEDLER, F.; MACHADO, E.; POLETTE, M.; BONILHA, L.E.C.; ZECCHIN, H.; FERREIRA, V.S. Programa de Orientação e Educação Ambiental para a Reserva Biológica Marinha do Arvoredo. In: SIMPÓSIO DE ECOSSISTEMAS BRASILEIROS, 4., Anais..., v. 3, Águas de Lindóia, 2-7 de abril de 1998, p.313-319.

MARCOVALDI, M.A.G.; MARCOVALDI, G.G. de. Marine turtles of Brazil: the history and structure of projeto TAMAR-IBAMA. Biological Conservation, v.91, p. 35-41, 1999.

MARCOVALDI, M.A.G.; SANTOS, A.J.B.; SANTOS, A.S.; SOARES, L.S.; LOPEZ, G.G.; GODFREY, M.H.; LÓPEZ-MENDILAHARSU, M.; FUENTES, M.M.P.B. Spatio-temporal variation in the incubation duration and sex ratio of hawksbill hatchlings: implication for future management. J. Therm. Biol., v. 44, p. 70-77, 2014. 
MARRONI, E.V.; ASMUS, M.L. Gerenciamento Costeiro: Uma proposta para o fortalecimento comunitário na gestão ambiental. Pelotas: Useb, 2005,149 p.

MATOS, J.K.E. DE. Um caso de responsabilidade ambiental na hotelaria: o Hotel Ville La Plage, Armação dos Búzios - RJ. Bol. Observatório Ambiental Alberto Ribeiro Lamego, Campos dos Goitacazes, v. 8, n. 1, p. 919, jan/jun, 2014.

MEIRELES, C.P.; CREED, J.C.; PIMENTEL, D. S. A. Educação Ambiental no controle da bioinvasão marinha por Coral-Sol (Tubastraea spp. Anthozoa, Dendrophylliidae) em Angra dos Reis (RJ, Brasil). Ambientalmente Sustentable, v. 2, p.1-21, 2016.

MEIRELES, C.P.; RIBEIRO, F. DE V.; ANDRADE, A.C. DE; FERREIRA, Y.C. DA S.; CREED, J. C. Implantação da primeira trilha interpretativa terrestre e subaquática em área de proteção ambiental na llha Grande (Angra dos Reis, RJ). In: CONGRESSO NACIONAL DE PLANEJAMENTO E MANEJO DE TRILHAS, 2., Anais..., 16-18 de outubro de 2013, Universidade do Estado do Rio de Janeiro, Rio de Janeiro, p. 76.

MMA. Gerência de Biodiversidade Aquática e Recursos Pesqueiros. Panorama da Conservação dos ecossistemas costeiros e marinhos no Brasil. Brasília: MMA/SBF/GBA, 2010,148 p.

MUSA, G. Sipadan: An Over-exploited Scuba-diving Paradise? In: GARROD, B.; WILSON, J.C. (Eds.). Marine ecotourism: Issues and Experiences. Clevedon: Channel View Publications, 2003, p.122-137.

NICOLODI, J.L.; ZAMBODI, A. Gestão Costeira In: MMA. MACRODiagnóstico da Zona Costeira e Marinha do Brasil. Brasília: MMA, 2008, p. 213-223.

O'CONNOR, S.; CAMPBELL, R.; KNOWLES, T.; CORTEZ, H. Whale Watching Worldwide; Tourism numbers, expenditures and expanding economic benefits. International Fund for Animal Welfare. Yarmouth Port, 2009, 295 p; disponível em: https://www.mmc.gov/wp.../whale watching worldwide.pdf, acesso em: 30.03.2018

OLIVEIRA, A.P.L. Aula de campo como mecanismo facilitador do EnsinoAprendizagem sobre os ecossistemas recifais em Alagoas. Alexandria, Revista de Educação, Ciência e Tecnologia, v. 6, n. 2, p. 163-190, 2013; disponível em: https://periodicos.ufsc.br/index.php/alexandria/article/view/ 37996 acesso em: 30.03.2018.

OLIVEIRA, M.R.; PITA, C.; GONÇALVES, J.M.S.; LEITE, L.; COSTA, C.; ERZINI, K. Ecotourism Snorkelling Routes at Marinha Beach (Algarve). Journal of Coastal Research, Special Issue, v. 61, p. 274-281, 2011.

OLIVEIRA, A.C.S. DE; STEINER, A.Q.; AMARAL, F.D.L; SANTOS, M.E.F. Percepção dos ambientes recifais da Praia de Boa Viagem (Recife/Pe) por estudantes, professores e moradores. OLAM - Ciência \& Tecnologia, Rio Claro (SP), v. 9, p.136-163, 2009. (CD-ROM) 
ORAMS, M. B. The Effectiveness of Environmental Education: Can We Turn Tourists into "Greenies"? Progress in Tourism and Hospitality Research, Canberra, v. 3, p. 295-306, 1997.

ORAMS, M.B. Marine Ecotourism in New Zealand: An Overview of the Industry and its management. In: GARROD, B.; WILSON, J. (Edit.) Marine Ecotourism: issues and Experiences. Clevendon: Channel View, 2003, p. 234-248.

PALAZZO, JR., J.T; BOTH, M. DO C. Guia dos Mamíferos Marinhos do Brasil. Porto Alegre: Sagra, 1988.

PALAZZO, J.R., J. T.; IÑíGUEZ, M.A.; HEVIA, M. A Worldwide Directory of Whale Watching Research. Comitê Científico da Comissão Internacional da Baleia: Cambridge, SC/5 6 / W W 8, 2004; disponível em: https://iwc.int/ acesso em: 23.abr.2018.

PANITZ, C.M.N. Projeto: Oficinas ecológicas em ecossistemas costeiros; uma proposta de educação ambiental In: PEDRINI, A. G. (ORG.). Educação Ambiental Marinha e Costeira no Brasil. Rio de Janeiro: EdUERJ/FAPERJ, 2010, p.181-199.

PAULA, A.T. DE.; RABINOVICI, A. Políticas Públicas de Ecoturismo no Brasil. In: NEIMAN, Z.; RABINOVICI, A. (Org.). Turismo e Meio Ambiente no Brasil. Barueri: Manole, 2010, p. 167-189.

PEDRINI, A. G. Introdução. In: PEDRINI, A. G. (Org.). O Contrato Social da Ciência unindo saberes na Educação Ambiental. Petrópolis: Vozes, 2002, p. 23-27.

PEDRINI A. G. Avaliação da Educação Ambiental no Ecoturismo (com Trilhas): Uma Proposta Metodológica de Qualidade Conceitual. OLAM Ciência e Tecnologia -, Rio Claro (SP), v. 7, n. 2, p. 83-106, 2006a. (CDROM)

PEDRINI, A. G. A Educação Ambiental com a Biodiversidade no Brasil: um ensaio. Revista Ambiente e Educação, Rio Grande, v.11, p. 63-74, 2006b.

PEDRINI, A. G. Avaliação da Educação Ambiental no Ecoturismo (com Trilhas): Uma Proposta Metodológica de Qualidade Conceitual. OLAM Ciência e Tecnologia - Rio Claro (SP), v. 7, n. 2, p. 83-106, 2006c. (CDROM)

PEDRINI, A. G. Ecoturismo, Interpretação e Educação Ambientais: Consensuando Conceitos. In: CONGRESSO NACIONAL DE ECOTURISMO, 6., Anais..., 8 a 11 de novembro de 2007, 20 p., Itatiaia, Rio de Janeiro.(CDROM)

PEDRINI, A. G. Educação Ambiental Marinha e Costeira no Brasil; aportes para uma síntese. In: PEDRINI, A. G. (Org.) Educação Ambiental Marinha e Costeira no Brasil. Rio de Janeiro: Eduerj, 2010, p. 19-32.

PEDRINI, A. G. Trilhas Marinhas no Brasil; uma síntese para a Educação Ambiental. In: CONGRESSO NACIONAL DE PLANEJAMENTO E MANEJO DE TRILHAS, 2., Anais...., 2013, p.1272-1279, Universidade do Estado do Rio de Janeiro, Rio de Janeiro (RJ), Brasil. (CD-ROM). 
PEDRINI, A. G. Ecoturismo marinho sustentável como educação ambiental transformadora e emancipatória em unidades de conservação marinha no Brasil: uma proposta inovadora da universidade à sociedade. In: GUERRA, A.F.S.; FIGUEIREDO, M.L. (Org.) Diálogo de Saberes e Fazeres; uma releitura dos 25 anos da trajetória da educação ambiental brasileira. p. 298-302, 2017; disponível em: http://www.reasul.org.br/index.php/bibliotecamainmenu-33/14-triade/destaques/ 1075-livro-dialogos-de-saberes-e-fazeresuma-releitura-dos-25-anos-da-trajetoria-da-educacao-ambiental-brasileira; acesso em: 30.03.18.

PEDRINI, A. G. Trilhas Interpretativas no Brasil: uma proposta para o ensino básico. AmbientalMente Sustentable, Coruña, v. 1, n. 25, p. 2018a (in press).

PEDRINI, A. G. Environmental education policies applied to marine and coastal environments in Brazil: gaps and challenges. In: GHILARDI-LOPES, N.; BERCHEZ, F. (Eds.) Marine and Coastal Environmental Education. Springer, Cham, 2018b (in press).

PEDRINI, A.G.; MERIANO, D. Avaliação da Qualidade do Ecoturismo Terrestre no Brasil: Estudo de Caso com uma empresa atuante em trilhas, RJ. In: CONGRESSO NACIONAL DE ECOTURISMO, 6., Anais..., 8-11 de novembro de 2007, Itatiaia, Rio de Janeiro.(CD-ROM)

PEDRINI A.G.; DE-PAULA J.C. Educação Ambiental: Críticas e Propostas. In: PEDRINI, A. G. (Org.) Educação Ambiental: Reflexões e Práticas Contemporâneas. 7 ed. Petrópolis: Vozes, 2011, p. 88-104.

PEDRINI A. G.; ANDRADE-COSTA E.; SILVA. V.G.; PINA R.S.; SABA M.; BERCHEZ F. Projeto EcoTurisMar: Uma Proposta de Educação/Interpretação Ambiental para o Ecoturismo Marinho em Áreas Protegidas. Estudo de Caso Preliminar no Parque Estadual da llha Anchieta, São Paulo, Brasil. In: SEMANA NACIONAL DE OCEANOGRAFIA, 21., Belém, Anais..., 2-8 de agosto de 2009, Aoceano. (CD-ROM)

PEDRINI, A.G.; BROTTO, D.; LOPES, M.C.; MESSAS, T. Gestão de Áreas Protegidas com Educação Ambiental Emancipatória pelo Ecoturismo Marinho: A Proposta do Projeto Ecoturismar. OLAM - Ciencia \& Tecnologia-, Rio Claro (SP), v. 3, p. 6-81, 2011; disponível em: http://www.periodicos.rc.biblioteca.unesp.br/index.php/olam/article/view/4967; accesss in: 1/08/2011.

PEDRINI, A.G; BROTTO, D. S.; MESSAS, T. P. Use evaluation in the I Refresher course in EE to the marine and coastal tourism (I CEAM). Revista eletrônica do Mestrado em Educação Ambiental (FURG), v. 28, p. 133147, 2012; disponível em: https://periodicos.furg.br/remea/article/view/3110; acesso em: 30.03.2018.

PEDRINI, A.G.; BROTTO, D. S.; LOPES, M.C.; FERREIRA, L. P.; GHILARDI, N.P. Percepções sobre Meio Ambiente e o mar por interessados em Ecoturismo Marinho na Área de Proteção Ambiental Marinha de Armação de Búzios, estado do Rio de Janeiro, RJ, Brasil. Revista Pesquisa em Educação Ambiental v. 8, p. 25-38, 2013a. 
PEDRINI, A. G; BROTTO, D.S.; PIMENTEL, D. S.; BEHRENDS, E.; SOARES, A.A.J; LOPES, M.C; RUA, M.B. Ecoturismar project: Efficacy evaluation of an experimental ecotouristic product at marine Environmental Protection Area of Armação de Búzios (APAMAB), state of Rio de Janeiro - Brazil. In: BIOINC, Arraial do Cabo, Anais...,15, 2013b, disponível em: https://www1.mar.mil.br/ieapm/publicacoes; accesss in: 30.11/2015.

PEDRINI, A. G.; BROTTO, D.S.; GHILARDI-LOPES, N.P; LOPES, M.C., FERREIRA, L.P. Environmental education and ecotourism concepts in Marine Protected Area of Armação de Búzios, Rio de Janeiro, Brazil: reflections for the adoption of coastal ecotourism. Revista Brasileira de Ecoturismo, São Paulo, v.8, n. 1, p. 59-73, 2015.

PEDRINI, A. G.; BROTTO, D.S.; PIMENTEL, D.S.; BEHRENDS, E.; MORAES, A. A. J. Marine Ecotourism applied for Emancipatory Environmental Education at Búzios Marine Protected Area, Rio de Janeiro, Brazil. Revista Brasileira de Ecoturismo, São Paulo, v. 9, p. 445-470. 2016a.

PEDRINI, A.G.; RHORMENS, M.S.; BROTTO, D. S. Emancipatory environmental education through community-based marine ecotourism; a methodological proposal with environmental sustainability. In: ARAÚJO, M.I.O.; SANTANA, C.G.; NEPOMUCENO, A. O. L. (Ed.), Environmental Educators: Paths to the Praxis. Aracaju: Criação Ed., 2016b, p. 47-62. (in portuguese)

PEDRINI, A. G.; COSTA, C.; NEWTON, T.; MANESCHY, F.S.; SILVA, V.G.; BERCHEZ, F.; SPELTA, L.; GHILARDI, N.P.; ROBIM, M. J. Efeitos ambientais da visitação turística em áreas protegidas marinhas: estudo de caso na Piscina Natural Marinha, Parque Estadual da Ilha Anchieta, Ubatuba, São Paulo, Brasil. OLAM - Ciência e Tecnologia, Rio Claro, v. 7, n. 1, p. 678696. 2007. (CD-ROM)

PEDRINI, A. G.; COSTA, C.; SILVA, V.G.; MANESCHY, F.S.; NEWTON, T.; BERCHEZ, F.A.; GHILARD, N.P.; SPELTA, L. Gestão de Áreas Protegidas e Efeitos da Visitação Ecoturística pelo Mergulho com Snorkel: O Caso do Parque Estadual da llha Anchieta (PEIA), Estado de São Paulo. Revista Eletrônica do Mestrado em Educação Ambiental (REMEA), Rio Grande, v. 20, p. 1-20, 2008a.

PEDRINI, A. G.; DUTRA, D.; ROBIM, M.J.; MARTINS, S.L. Gestão de áreas protegidas e avaliação da educação ambiental no ecoturismo: Estudo de caso com o projeto Trilha subaquática - Educação ambiental nos ecossistemas marinhos - no Parque Estadual da Ilha Anchieta, Ubatuba, São Paulo, Brasil. OLAM - Ciência e Tecnologia, Rio Claro (SP), v. 8, n.2, p. 31-55, 2008b, (CD ROM).

PEDRINI, A.G.; MANESCHY, F.S.A.; SILVA, V.G.; NEWTON, T.; CAMPOS, P.H.; COSTA, C.; ANDRADE-COSTA, E. EduMar-Projeto de educação/interpretação ambiental marinha para o mergulho recreativo. In: PEDRINI, A. G. (Org.). Educação Ambiental Marinha e Costeira no Brasil. Rio de Janeiro: EdUERJ, 2010a, p. 143-166. 
PEDRINI, A. G.; MESSAS, T.P.; PEREIRA, E.S.; GHILARDI-LOPES, N.P; BERCHEZ, F.A. Environmental education through ecotourism in a marine trail in the state park of Anchieta island, Ubatuba (SP). Revista Brasileira de Ecoturismo, São Paulo, v. 3, p. 428-459, 2010b.

PEDRINI, A. G.; URSI, S.; BERCHEZ, F.; CORREIA, M. D.; SOVIERZOSKI, H. H.; MOCHEL, F. Metodologias em Educação Ambiental para a conservação socioambiental dos ecossistemas marinhos. In: PEDRINI, A. G.; SAITO, C.H. (Org) Paradigmas Metodológicos em Educação Ambiental. Petrópolis: Vozes, 2014, p. 132-151.

PEDRINI, A. G; KREMER, L; BROTTO, D.S.; SILVA, V.R.F. DA. Emblematic Projects of Marine and Coastal Environmental Education in Brazil. In: GHILARDI-LOPES, N. P.; BERCHEZ, F. (Eds.) Marine and Coastal Environmental Education. Springer, Cham, 2018, (in press).

PEGAS, F.; COGHLAN, A.; ROCHA, V. An exploration of a mini-guide program: Training local children in sea turtle conservation and ecotourism in Brazil. Journal of Ecotourism, v.11, p. 48-55, 2012.

PEGAS, F. DE V.; COGHLAN, A.; STRONZA, A.; ROCHA, V. For love or for Money? Investigating the impact of na ecotourism programme on local residents'assigned values towards sea turtles. Journal of Ecotourism, v.12, n. 2, p. 90-106, 2013.

PETREAS, C.P. Scuba Diving: an alternative Form of Coastal Tourism for Greece? In: GARROD, B.; WILSON, J.C. (Eds.), Marine ecotourism: Issues and Experiences. Channel View Publications, Clevedon, 2003, p. 215-232.

PIMENTEL, C. E. Gestão Ambiental para o turismo. In: QUEIROZ, O.T. (Org.) Turismo e Ambiente: Temas Emergentes. Campinas: Alínea, 2003, p. 49-74.

PIMENTEL, D. DE S; PEDRINI, A. G; KAWABE, L. DE A; ROBIM, M. DE J.; BERCHEZ, F.; MEIRELES, C.P. Opportunities and challenges to implement Environmental Education in Brazilian Coastal and Marine Protected Areas. In: GHILARDI-LOPES, N. P.; BERCHEZ, F. (Eds.) Marine and Coastal Environmental Education. Springer, Cham, 2018, (in press).

PIRES, P. DOS S. Entendendo o ecoturismo. In: TRIGO, L.G.G. (Ed.) Análises Regionais e Globais do Turismo Brasileiro. São Paulo: Roca, 2005, p. 483-494.

PRATES, A.P.; PEREIRA, P.M.; DUARTE, A.E.M.; HAZIN, M.C.; FERREIRA, B.P.; REINHARD, M. Campanha de conduta consciente em ambientes recifais. In: PEDRINI A. G. (Org.) Educação Ambiental Marinha e Costeira no Brasil. Rio de Janeiro: Eduerj, 2010, p.115-131.

QUINTAS, J.S. Os dez anos da Política Nacional de Educação Ambiental e de sua implementação na esfera da gestão ambiental federal. In: SEMINÁRIO "10 ANOS DA POLÍTICA NACIONAL DE EDUCAÇÃO AMBIENTAL: AVANÇOS E NECESSIDADES EM BUSCA DA EDIFICAÇÃO DE UMA SOCIEDADE SUSTENTÁVEL", 1., Anais..., 27-28/04/09, Brasília, Congresso Nacional/MMA. 
RAHAKBAUW, R.S.; TENIWUT, W.A.; RENJAAN, M.R.; HUNGAN, M. Increase Economic Valuation of Marine Ecotourism Spots in Small Islands. IOP Conf. Series: Earth and Environmental Science 89: 012037, 2017; disponível em: https://www.researchgate.net/journal/17551315 IOP Conference Series Earth and Environmental Science/2; acesso em: 30.03.2018.

RANGEL, M.O.; DENTINHO, T.P.; ARAÚJO, G.; LOPES, J.; GONÇALVES, J.M.S.; ERZINI, K. Cost analysis of underwater routes (apnea) on the marinha beach (Algarve). Portuguese J. Regional Studies, p. 77-89. 2009.

RHORMENS, M. S.; PEDRINI, A. G.; GHILARDI-LOPES, N. P. Implementation feasibility of a marine ecotourism product on the reef environments of the marine protected area of Tinharé and Boipeba Islands (Cairu, Bahia, Brazil). Ocean \& Coastal Management, n. 139, p. 1-11. 2017.

RODRIGUES, A.B. Ecoturismo - limites do eco e da ética. In: RODRIGUES, B. (Org.). Ecoturismo no Brasil: possibilidades e limites. São Paulo: Contexto, 2003, p. 29-45.

RUA, M.B.; PEDRINI, A. G.; BROTTO, D.S.; BERNARDES, L.; MARIANO, D.; FONSECA, L.B.; NUNES, R.M. Percepção ambiental do ambiente marinho por crianças no Rio de Janeiro, Brasil. Revista de Biociências, Taubaté, v. 22, n. 1, p. 44-54, 2015.

RUSCHMANN, D. Turismo e Planejamento Sustentável; a Proteção do Meio Ambiente. 12 ed. Campinas: Papirus, 2005, 199 p.

SAITO, C.H.; FIGUEIREDO, J.; VARGAS, I.A. Educação Ambiental Freiriana no contexto de formação de educadores ambientais. In: PEDRINI A. G; SAITO, C.H. (Org.) Paradigmas Metodológicos em Educação Ambiental. Petrópolis: Vozes, 2014, p. 71-81.

SANCHEZ, C. Os nós, os laços e a rede: considerações sobre a institucionalização da Educação Ambiental no Brasil. 2008. Pontifícia Universidade Católica. Tese (Doutorado em Educação). Rio de Janeiro.

SANTOS, G.S., BURGOS, D.C., LIRA, S.M.A., SCWAMBORN, R. The Impact of Trampling on Reef Macrobenthos in Northeastern Brazil: How Effective are Current Conservation Strategies? Environmental Management, v. 56, n. 4, p. 847-858. 2015.

SÃO PAULO. Passaporte para as trilhas do estado de São Paulo. São Paulo: Governo do Estado de São Paulo, 2008, 101 p.

SILVA JR, J.M. Parque Nacional Marinho de Fernando de Noronha: Uso Público, Importância Econômica e Proposta de Manejo. In: Simpósio de Áreas Protegidas, Conservação no Âmbito do Cone Sul, 2., Anais..., Pelotas, 2003, p. 335-342.

SILVA JR, J.M. DA. Projeto Golfinho Rotador: Pesquisa e Conservação do Golfinho-Rotador Stenella longirostris Gray, 1828 (Cetacea: Delphinidae) no Arquipélago de Fernando de Noronha, Brasil. In: MOHR, L.V., CASTRO, J.W.A., COSTA, P.M.S., ALVES, R.J.V. (Org.) Ilhas Oceânicas Brasileiras: 
da Pesquisa ao Manejo. Brasília: Ministério do Meio Ambiente, 2009, p. 301 327.

SILVA JR, J.M. DA; GERLING. C.; VENTURI, E.; ARAUJO, L.L.; SILVA, F. J. L. Férias Ecológicas: um programa de educação ambiental marinha em Fernando de Noronha. In: PEDRINI, A. G. (Ed.). Educação Ambiental Marinha e Costeira no Brasil. Rio de Janeiro: EdUERJ, 2010, p. 201-226.

SILVA, J.N.; GHILARDI-LOPES, N. P. Indicators of the impacts of tourism on hardbottom benthic communities of Ilha do Cardoso State Park (Cananéia) and Sonho Beach (Itanhaém), two southern coastal areas of São Paulo State (Brazil). Ocean \& Coastal Management, v. 58, p. 1-8. March.

SORRENTINO, M., TRAJBER, R., MENDONÇA, P., FERRARO JUNIOR, L.A. Educação Ambiental como Política Pública. Educação e Pesquisa (USP), São Paulo, v. 31, n. 2, p. 285-299.

TOWSEND, C. Marine ecotourism through Education: a case study of divers in the Virgin Islands. In: GARROD, B.; WILSON J.C. (Ed.), Marine ecotourism: Issues and Experiences. Channel View Publications, Clevedon, 2003, p. 138-154.

TUNALA, P.L.; BITTAR, V.T.; PEDRINI. A. G. Efeitos Ambientais Negativos de Mergulhadores em Apnéia (com 'Snorkel') na Praia de João Fernandes, Área de Proteção Ambiental Marinha de Armação dos Búzios, Rio de Janeiro, Brasil. In: CONGRESSO DE ECOLOGIA DO BRASIL, 6., Anais..., outubro de 2013, 2 p.(CD-ROM).

WEGNER, E. Proposta metodológica para implantação de trilhas subaquáticas na llha de Porto Belo, Porto Belo, SC. 2002. 86 f. Dissertação (Mestrado em Turismo e Hotelaria), Universidade do Vale do Itajaí, Itajaí.

WEGNER, E.; TONIOLI, F.C.; CABRAL, D.Q. Underwater trails: a new possibility on marine tourism. Journal of Coastal Research, Lawrence, special issue, n. 39, 2004.

WORLD TOURISM ORGANIZATION (WTO) Global Code of Ethics for Tourism. 1999; disponible: http://ethics.unwto.org/content/global-code-ethicstourism; access: 07/03/2018.

WORLD TOURISM ORGANIZATION (WTO) Desenvolvimento Sustentável do Ecoturismo: Uma Compilação de Boas Práticas. São Paulo: Roca, 2004, $245 \mathrm{p}$.

ZAÚ, A.S. A conservação de áreas naturais e o Ecoturismo. Revista Brasileira de Ecoturismo, São Paulo, v. 7, n. 2, p. 290-321. 2014.

ZAÚ, P. N. S. Proposta de implementação de Trilha interpretativa na Praia do Forno (Arraial do Cabo/RJ) como ferramenta de Educação Ambiental para Unidades de Conservação Marinhas. 2018. 81f. Monografia. (Bacharel em Oceanografia), Faculdade de Oceanografia, Universidade do Estado do Rio de Janeiro, Rio de Janeiro. 2018. 


\section{Nota:}

${ }^{1}$ Caiçaras are one of the several traditional populations which developed along centuries of ethnic mix between indigenous, European and (less often in this case) enslaved African people. They live along the Southern portion of the Atlantic Forest and rely mostly on fishing and small-scale agriculture

Alexandre de Gusmão Pedrini: Universidade do Estado do Rio de Janeiro. Rio de Janeiro, RJ, Brasil.

E-mail: pedrini@globo.com

Link para o currículo Lattes: http://lattes.cnpq.br/6918956483557789

Data de submissão: 04 de julho de 2018

Data de recebimento de correções: 23 de julho de 2018

Data do aceite: 23 de julho de 2018

Avaliado anonimamente 